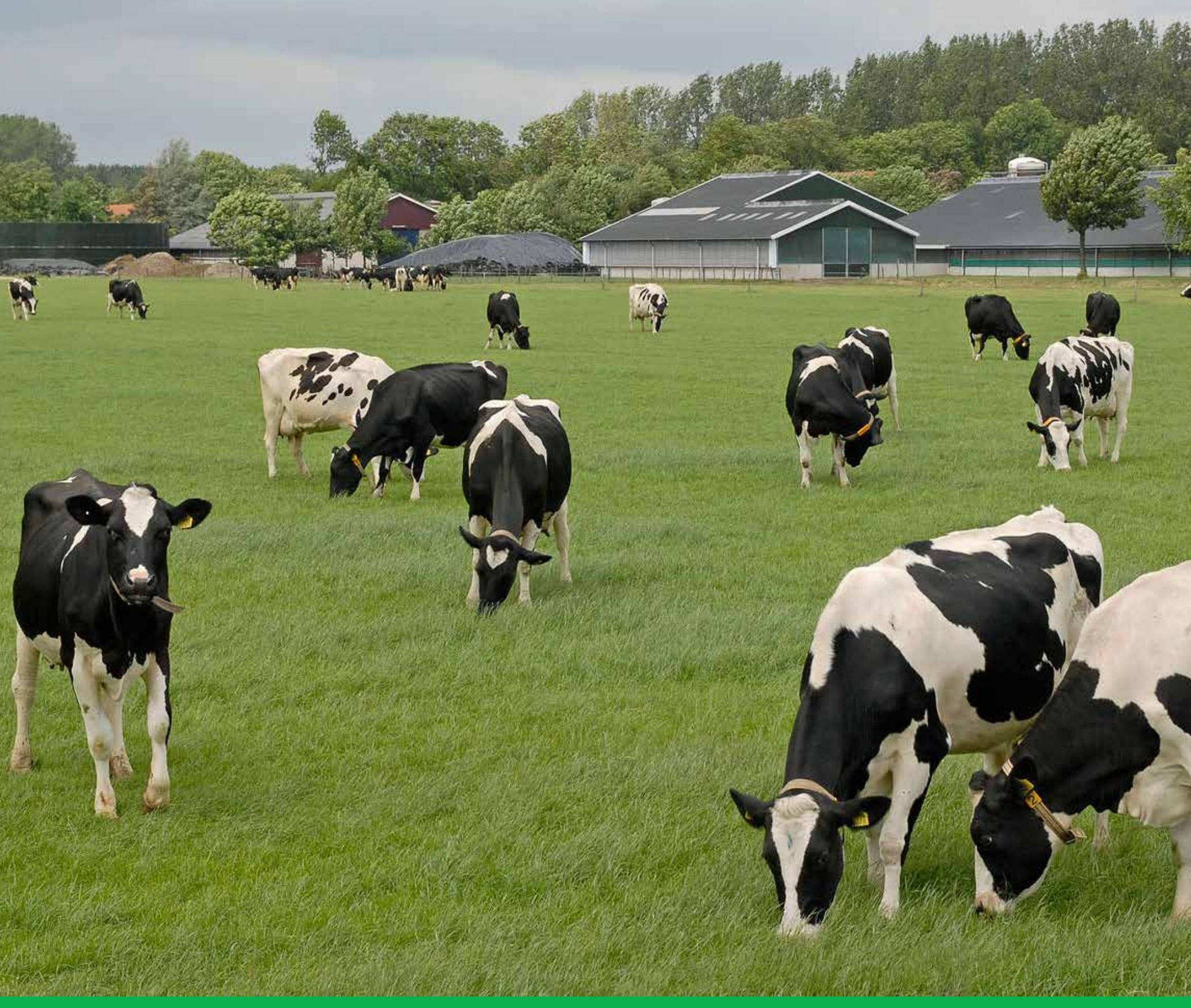

Mestafzetkosten, mestafzetprijzen en mestboetes

Tanja de Koeijer en Harry Luesink 



\section{Mestafzetkosten, mestafzetprijzen en mestboetes}

Tanja de Koeijer en Harry Luesink

Dit onderzoek is uitgevoerd door Wageningen Economic Research in opdracht van Commissie Deskundigen Meststoffenwet en gefinancierd door het ministerie van Landbouw, Natuur en Voedselkwaliteit, in het kader van het Beleidsondersteunend/ onderzoeksthema 'Mest, milieu en llimaat' (projectnummer BO-43-012.02-003)

Wageningen Economic Research

Wageningen, maart 2019

NOTA

2019-016 
Tanja de Koeijer en Harry Luesink, 2019. Mestafzetkosten, mestafzetprijzen en mestboetes. Wageningen, Wageningen Economic Research, Nota 2019-016. 30 blz.; 11 fig.; 1 tab.; 7 ref.

Het ministerie van Landbouw, Natuur en Voedselveiligheid heeft de Commissie Deskundigen Meststoffenwet (CDM) gevraagd of de huidige boetes voor het onjuist afzetten van mest nog gebaseerd zijn op een reëel beeld van het economisch voordeel dat dit kan opleveren. De CDM heeft vervolgens Wageningen Economic Research gevraagd om de mestafzetkosten voor melkvee-, pluimvee- en varkensbedrijven in beeld te brengen. Deze bedroegen in 2016 achtereenvolgens $6.000,11.000$ en 51.000 euro per bedrijf.

Ook is gevraagd om de minimaal benodigde boete per kilogram onjuist afgezette stikstof en fosfaat te berekenen afhankelijk van de pakkans. Uitgaande van een pakkans van $100 \%$ bedraagt deze boete voor rundvee-, pluimvee- en varkensmest respectievelijk 1,90; 0,20 en 1,60 euro per kg N. Voor fosfaat bedraagt deze boete 2,$90 ; 0,30$ en 2,50 euro per $\mathrm{kg} \mathrm{P}_{2} \mathrm{O}_{5}$.

Ten slotte is gevraagd om na te gaan in hoeverre de gehanteerde methodiek voor het berekenen van de boetes aansluit bij de handhavingspraktijk van de meststoffenwet en bij het bestraffen van economische delicten.

The Ministry of Agriculture, Nature and Food Quality asked the Scientific Committee of the Manure Act $(C D M)$ to determine whether the current penalties for the improper disposal of manure are still based on a realistic picture of the economic benefits to be gained. The CDM then asked Wageningen Economic Research to map out the manure disposal costs for dairy cattle, poultry and pig farms. In 2016, they amounted to $6,000,11,000$ and 51,000 euros per farm, respectively.

Wageningen Economic Research was then asked to calculate the minimum required penalty per kilo of improperly discarded nitrogen and phosphate, depending on the chance of detection. Based on a $100 \%$ chance of detection, the penalty for cattle, poultry and pig manure is $1.90,0.20$ and 1.60 euros per kilo of $\mathrm{N}$, respectively. For phosphate, the penalty is $2.90,0.30$ and 2.50 euros per kilo of $\mathrm{P}_{2} \mathrm{O}_{5}$. Lastly, they were asked to check the extent to which the method used to calculate the penalties is consistent with enforcement of the Manure Act and with the penalties for economic offences.

Trefwoorden: Mest, afzetkosten, afzetprijzen, boetes

Dit rapport is gratis te downloaden op https://doi.org/10.18174/471385 of op www. wur. nl/economicresearch (onder Wageningen Economic Research publicaties).

(C) 2019 Wageningen Economic Research

Postbus 29703, 2502 LS Den Haag, T 07033583 30, E communications.ssg@wur.nl, www. wur.nl/economic-research. Wageningen Economic Research is onderdeel van Wageningen University \& Research.

\section{(cc) BY-NC}

Wageningen Economic Research hanteert voor haar rapporten een Creative Commons Naamsvermelding 3.0 Nederland licentie.

(C) Wageningen Economic Research, onderdeel van Stichting Wageningen Research, 2019 De gebruiker mag het werk kopiëren, verspreiden en doorgeven en afgeleide werken maken. Materiaal van derden waarvan in het werk gebruik is gemaakt en waarop intellectuele eigendomsrechten berusten, mogen niet zonder voorafgaande toestemming van derden gebruikt worden. De gebruiker dient bij het werk de door de maker of de licentiegever aangegeven naam te vermelden, maar niet zodanig dat de indruk gewekt wordt dat zij daarmee instemmen met het werk van de gebruiker of het gebruik van het werk. De gebruiker mag het werk niet voor commerciële doeleinden gebruiken.

Wageningen Economic Research aanvaardt geen aansprakelijkheid voor eventuele schade voortvloeiend uit het gebruik van de resultaten van dit onderzoek of de toepassing van de adviezen.

Wageningen Economic Research is ISO 9001:2008 gecertificeerd.

Wageningen Economic Research Nota 2019-016 | Projectcode 2282200483

Foto omslag: Wageningen University \& Research 


\section{Inhoud}

Samenvatting $\quad \mathbf{5}$

S.1 Belangrijkste uitkomsten $\quad 5$

$\begin{array}{lll}\text { S.2 Verantwoording } & 5\end{array}$

$\begin{array}{lll}1 & \text { Inleiding } & 7\end{array}$

$2 \quad$ Boetes bij overtreding van de Meststoffenwet $\quad 8$

2.1 Algemeen $\quad 8$

2.2 Boete voor het overschrijden van de gebruiksnormen $\quad 8$

2.3 Boetes voor administratieve onjuistheden en/of afwijkingen administratie $\quad 8$

2.4 Boetes in het kader van het strafrecht 9

2.5 Boetes bij andere economische delicten 9

$3 \quad$ Mestafzetkosten per dier en per gebied $r$

4 De minimale hoogte van boete voor overschrijding van de gebruiksnormen

4.1 Aanpak 12

4.2 Berekeningswijze van de hoogte van de boete $\quad 14$

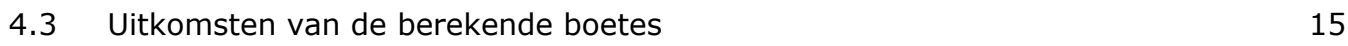

4.4 Vaststelling huidige boete voor overschrijding van de gebruiksnormen $\quad 19$

5 Discussie $\quad 20$

$\begin{array}{lll}5.1 & \text { Reflectie op berekening huidige boete } & 21\end{array}$

$\begin{array}{ll}\text { Literatuur en websites } & 24\end{array}$

Bijlage 1 Minimaal benodigde boete bij pakkans=100\% en
fraudeprikkel $=1$

Bijlage 2 Minimaal benodigde boete bij oplopende pakkans $(0,1-1 \%)$ en fraudeprikkel van 0,$6 ; 1$ en 1,4 



\section{Samenvatting}

\section{S.1 Belangrijkste uitkomsten}

\section{Mestafzetkosten per bedrijf}

De mestafzetkosten van bedrijven zijn in de periode 2010-2016 in de rundvee- en varkenshouderij gestegen en in de pluimveehouderij gedaald. De gemiddelde mestafzetkosten verschillen sterk per sector en bedroegen in 2016 voor de melkvee-, pluimvee- en varkenshouderijbedrijven achtereenvolgens circa $6.000,11.000$ en 51.000 euro per bedrijf. De mestafzetkosten zijn het hoogst in het mestconcentratiegebied Zuid.

\section{Minimaal benodigde boete voor overschrijding van de gebruiksnormen}

De minimaal benodigde boete voor stikstof bedraagt voor rundvee-, pluimvee- en varkensmest respectievelijk 1,90; 0,20 en 1,60 euro per $\mathrm{kg} \mathrm{N}$. Voor fosfaat bedraagt deze boete 2,90;0,30 en 2,50 euro per $\mathrm{kg} \mathrm{P}_{2} \mathrm{O}_{5}$. Hierbij is uitgegaan van een prijsverhouding van stikstof:fosfaat van $7: 11$, de mestafzetprijzen van 2016, een fraudeprikkel gelijk aan één en een pakkans van $100 \%$.

Indien de pakkans 10 of 5\% bedraagt, moeten de minimaal benodigde boetes met een factor 10 en 20 worden verhoogd. Bij zeer kleine pakkansen $(<1 \%)$ voldoet de gehanteerde berekeningsmethode voor de minimaal benodigde boete voor stikstof en fosfaat niet. Bij deze kleine pakkansen zijn de berekende boetes extreem hoog en onevenredig.

\section{Aansluiting bij huidige handhavingspraktijk}

Omdat er veel onzekerheid is over de daadwerkelijke pakkans bij het onjuist afzetten van mest lijkt het zinvol om de minimaal benodigde hoogte van de boetes te baseren op de uitgangspunten die gehanteerd waren voor berekening van de huidige boetes. Deze uitgangspunten sluiten aan bij de handhaving van economische delicten door de Belastingdienst. Op basis van deze uitgangspunten en de huidige mestafzetkosten zouden de huidige boetes voor het overschrijden van de gebruiksnormen niet naar boven hoeven te worden bijgesteld vanwege de gestegen mestafzetkosten in deze periode.

\section{S.2 Verantwoording}

Het ministerie van Landbouw, Natuur en Voedselveiligheid heeft de Commissie Deskundigen Meststoffenwet (CDM) gevraagd in hoeverre de huidige boetes voor het onjuist afzetten van mest nog gebaseerd zijn op een reëel beeld van het mogelijk economisch voordeel dat dit kan opleveren. De CDM heeft vervolgens Wageningen Economic Research gevraagd om:

- de afzetkosten voor rundvee-, varkens- en pluimveemest per bedrijfstype en per onderscheiden mestconcentratiegebied over de afgelopen vijf jaar in beeld te brengen.

- de minimaal benodigde boete per kilogram onjuist afgezette stikstof en fosfaat te berekenen. Hierbij wordt aangenomen dat de boete groter of gelijk is aan de mestafzetkosten maal de fraudeprikkel gedeeld door de pakkans.

- na te gaan in hoeverre de zo berekende boetes aansluiten bij de handhavingspraktijk van de meststoffenwet, de wijze waarop de huidige boetes zijn bepaald en in hoeverre de berekende boetes aansluiten bij het bestraffen van economische delicten.

Uitgegaan is van een economisch rationeel handelend persoon waarbij de fraudeprikkel over het algemeen dicht bij één ligt. De pakkans is gedefinieerd als het aandeel nutriënten waarvan is aangetoond dat de gebruiksnormen zijn overschreden ten opzichte van de totale overschrijding van de gebruiksnormen. De pakkans ligt per definitie tussen de $0 \%$ (nooit) en $100 \%$ (altijd). 


\section{Summary}

\section{S.1 Main outcomes}

\section{Manure disposal costs per farm}

In the period 2010-2016, the manure disposal costs of farms in the cattle and pig sectors increased, while the costs decreased in the poultry sector. The average manure disposal costs differ significantly in each sector and in 2016 were around 6,000, 11,000 and 51,000 euros per farm for dairy cattle, poultry and pig farms, respectively. The manure disposal costs are highest in the South (Zuid) area where manure is concentrated.

\section{Minimum required penalty for exceeding the application standards}

The minimum required penalty for nitrogen is $1.90,0.20$ and 1.60 euros per kilo of $\mathrm{N}$ for cattle, poultry and pig manure, respectively. For phosphate, this penalty is $2.90,0.30$ and 2.50 euros per kilo of $\mathrm{P}_{2} \mathrm{O}_{5}$. This is based on a price ratio for nitrogen:phosphate of $7: 11$, the manure disposal prices of 2016, a fraud incentive equal to one and a $100 \%$ chance of detection.

If the chance of detection is $10 \%$ or $5 \%$, the minimum required penalties must be increased by a factor of 10 and 20 respectively. In case of very small chances of detection $(<1 \%)$, the calculation method used is not adequate for the minimum required penalty for nitrogen and phosphate. For these small chances of detection, the calculated penalties are extremely high and disproportionate.

\section{Compatibility with current enforcement practice}

Because there is considerable uncertainty about the actual chance of detection when manure is disposed of improperly, it is appropriate to base the minimum required size of the penalties on the principles that were used to calculate the current penalties. These principles are consistent with the enforcement of economic offences by the Belastingdienst (Dutch Tax and Customs Administration). Based on these principles and the current manure disposal costs, the current penalties for violating the application standards do not need to be revised upwards due to the increased manure disposal costs in this period.

\section{S.2 Accountability}

The Ministry of Agriculture, Nature and Food Quality asked the Scientific Committee of the Manure Act (CDM) to determine whether the current penalties for the improper disposal of manure are still based on a realistic picture of the economic benefits to be gained. The CDM then asked Wageningen Economic Research to:

- map out the disposal costs for cattle, pig and poultry manure for each farm type and for each individual area where manure is concentrated over the past five years.

- calculate the minimum required penalty per kilo of improperly discarded nitrogen and phosphate. Here it is assumed that the penalty is greater than or equal to the manure disposal costs times the fraud incentive divided by the chance of detection.

- check the extent to which the penalties calculated in this way are consistent with the enforcement practices of the Manure Act and the penalties for economic offences.

This is based on a person who acts in an economically rational way and where a fraud incentive is generally close to one. The chance of detection has been defined as the share of nutrients for which it was demonstrated that the application standards were violated compared to the total violation of the application standards. The chance of detection is by definition between $0 \%$ (never) and $100 \%$ (always). 


\section{$1 \quad$ Inleiding}

In het kader van de derogatie 2018-2019 heeft het ministerie van LNV op verzoek van de Europese Commissie een handhavingsstrategie voorbereid. In de nota 'Versterkte Handhavingsstrategie Mest' (LNV, 2018) wordt aangegeven welke maatregelen de minister van LNV neemt om de naleving van de mestwet te bevorderen en fraude tegen te gaan. Eén van de aanbevelingen in deze nota betreft een analyse uit te voeren in hoeverre de huidige boetes voor het onjuist afzetten van mest nog gebaseerd zijn op een reëel beeld van het mogelijk economisch voordeel dat dit kan opleveren. De huidige boetes voor het onjuist afzetten van mest zijn in 2005 vastgesteld en sindsdien niet aangepast (Auditdienst Rijk, 2018), terwijl de mestafzetkosten in de tussenliggende periode zijn gestegen. Daarnaast wordt aanbevolen om onderzoek te doen of differentiatie naar soort mest en/of grondsoort gewenst is omdat het economisch voordeel per producentengroep verschillend is.

Tegen deze achtergrond heeft het ministerie van LNV aan de Commissie Deskundigen Meststoffenwet (CDM) gevraagd om:

- de afzetkosten voor verschillende mestsoorten per bedrijfstype over de afgelopen vijf jaar in beeld te brengen;

- de afzetkosten van mest af te zetten tegen het economisch voordeel van fraude door daarbij in beeld te brengen wat de pakkans bij benadering is geweest zodat het daadwerkelijk economisch voordeel in beeld kan worden gebracht;

- aan te geven of eventuele verschillen in mestafzetkosten tussen regio's of mestsoorten en bedrijfstypen een differentiatie tussen sectoren en/of regio's rechtvaardigen, mede gelet op de pakkans.

In overleg met het ministerie van LNV heeft de CDM aan Wageningen Economic Research gevraagd om:

- De afzetkosten voor rundvee-, varkens- en pluimveemest per bedrijfstype en per onderscheiden mestconcentratiegebied over de afgelopen vijf jaar in beeld te brengen.

- De minimaal benodigde boete per kilogram onjuist afgezette stikstof en fosfaat te berekenen. Hierbij wordt aangenomen dat de boete groter of gelijk is aan de mestafzetkosten maal de fraudeprikkel gedeeld door de pakkans.

Na bespreking van de resultaten met de CDM, heeft de CDM vervolgens Wageningen Economic Research gevraagd om:

- Na te gaan in hoeverre de zo berekende boetes aansluiten bij de handhavingspraktijk van de meststoffenwet, de wijze waarop de huidige boetes zijn bepaald en in hoeverre de berekende boetes aansluiten bij het bestraffen van economische delicten.

Voor de beantwoording van de laatste vragen is een workshop gehouden met handhavers van de meststoffenwet van RVO, NVWA en het Openbaar Ministerie. De tijdens de workshop verkregen inzichten zijn weergegeven in hoofdstuk 2.

Vervolgens beschrijft hoofdstuk 3 de ontwikkeling van de mestafzetkosten waarna in hoofdstuk 4 wordt ingegaan op de vraag hoe hoog de boetes volgens de gestelde voorwaarden zouden moeten zijn. Na de discussie in hoofdstuk 5 wordt het rapport afgesloten in hoofdstuk 6 met de conclusies. 


\section{Boetes bij overtreding van de Meststoffenwet}

\section{$2.1 \quad$ Algemeen}

Bij overtredingen in het kader van de mestwetgeving kunnen drie soorten boetes voor het onjuist afzetten van mest worden gegeven:

1. Boetes voor het: overschrijden van de gebruiksnormen/het niet voldoen aan de verantwoordingsplicht, niet voldoen aan de mestverwerkingsplicht, niet voldoen aan de verantwoorde groei melkveehouderij, niet voldoen aan grondgebondenheid in het kader van bestuursrecht en vastgelegd in de mestwetgeving (artikel 57, 58, 58a en 59).

2. Boetes voor het niet voldoen aan de administratieve verplichtingen in het kader van bestuursrecht en vastgelegd in de mestwetgeving (artikel 57, 58 en 59; bijlage M van de uitvoeringsregeling). Dat zijn boetes op basis van geconstateerde administratieve onjuistheden en/of geconstateerde afwijkingen van de praktijk met de administratie.

3. Boetes voor overtredingen rondom mest die opgelegd worden in het kader van het wetboek van strafrecht (artikel 23); boetes voor fraude (bijvoorbeeld valsheid in geschrifte).

\subsection{Boete voor het overschrijden van de gebruiksnormen}

Voor het niet voldoen aan de gebruiksnormen als gevolg van het onjuist afzetten en/of registreren van stikstof en fosfaat kunnen ondernemers worden beboet. Deze boete bedraagt 7 en 11 euro per kg voor respectievelijk stikstof $(\mathrm{N})$ en fosfaat $\left(\mathrm{P}_{2} \mathrm{O}_{5}\right)$. Deze boetes zijn in 2005 vastgesteld. De boete voor het niet goed afzetten van mest is gebaseerd op het wederrechtelijk verkregen economisch voordeel plus een bestraffend element. Hiertoe is uitgegaan van de verwachte afzetkosten van mest over langere afstand waarbij deze kosten zijn gemiddeld over de kosten voor de afzet van graasdiermest, varkensmest, pluimveemest etc. Daarbij is het principe gehanteerd dat het bestraffend deel $100 \%$ van het economisch voordeel is (Auditdienst Rijk, 2018). Of te wel de vastgestelde boete is gebaseerd op de onterecht niet-gemaakte mestafzetkosten maal twee.

\subsection{Boetes voor administratieve onjuistheden en/of afwijkingen administratie}

De boetes voor administratieve onjuistheden en/of afwijkende administratie met de werkelijkheid zijn niet gebaseerd op het opzettelijk onjuist administreren (Bijlage M). Deze boetes van 100, 200 respectievelijk 300 euro (bijlage $M$ ) zijn voor een intermediair, gezien de kleine pakkans, niet afschrikwekkend.

Het is wel mogelijk om tot hogere boetes te komen door boetes te stapelen. Ook kent de meststoffenwet bij dit soort overtredingen de mogelijkheid om een Last onder Dwangsom (LOD) op te leggen.

Het doel van de Last onder Dwangsom is het voorkomen van een overtreding of de overtreding ongedaan maken. Dit wordt gedaan door het eventueel economisch voordeel af te romen en/of vanwege handhavingsbelang. Dit soort bedragen zullen een meer afschrikkende werking hebben. Echter, verwacht wordt dat het waarschijnlijk effectiever is als bij het opleggen van dit type boetes meer maatwerk kan worden geleverd zodat bij grotere overtredingen de opgelegde boetes ook hoger kunnen zijn. Daarnaast kunnen de klanten van een intermediair (veehouders en akkerbouwers) een boete opgelegd krijgen, indien ze via de intermediair in overtreding zijn geraakt. 
Bij zowel boetes voor het overschrijden van de gebruiksnormen als die voor administratieve onjuistheden kunnen ook medeplegers worden beboet.

\subsection{Boetes in het kader van het strafrecht}

Naast boetes in het kader van het bestuursrecht kunnen er boetes in het kader van het strafrecht worden opgelegd. De overstap van bestuursrecht naar strafrecht wordt doorgaans gemaakt bij:

- veelvuldige recidive;

- zeer grote omvang;

- moreel verwijtbare gedragingen;

- zeer complexe onderzoeken.

In de praktijk is het zo dat boeren vrijwel alleen via het bestuursrecht worden aangepakt en intermediairs zowel via het bestuursrecht als via het strafrecht. Volgens artikel 23 uit het Wetboek van Strafrecht kunnen bij overtredingen volgens het strafrecht de volgende maximale bestuurlijke boetes worden opgelegd (Meststoffenwet is hier ook aan gelinkt): deze bedraagt voor een natuurlijk persoon 83.000 euro en voor een rechtspersoon 830.000 euro.

In de workshop met handhavers is aangegeven dat fraude op zich geen strafbaar feit is. Wat wel strafbaar is, is valsheid in geschrifte. Bij 'valsheid in geschrifte' met betrekking tot de mestwetgeving mag voor een rechtspersoon de zesde categorie worden toegepast. Daarnaast is het op basis van artikel 23 lid 7, ook mogelijk dat als de zesde categorie geen passende bestraffing toelaat dat dan een geldboete kan worden opgelegd van ten hoogste $10 \%$ van de jaaromzet van de rechtspersoon in het boekjaar voorafgaande aan de uitspraak of strafbeschikking. Veroordelingen in het kader van strafrecht werken in het algemeen beter dan die in het kader van bestuursrecht. Dit komt doordat in het strafrecht meer maatwerk kan worden geleverd. Er kunnen niet alleen hogere boetes worden opgelegd, maar ook taakstraffen, beslaglegging op het wagenpark, intrekken van de erkenning, etc. Dit soort straffen geldt als effectiever dan een boete.

\subsection{Boetes bij andere economische delicten}

De huidige boetes voor het onjuist afzetten van mest zijn gebaseerd op het wederrechtelijk verkregen economisch voordeel met daarboven op een even groot bestraffend element (Auditdienst, 2018). Deze aanpak sluit aan bij de wijze waarop de Belastingdienst de door haar op te leggen boetes vaststelt. Ook de Belastingdienst gaat uit van het economisch voordeel dat verkregen wordt door een onjuiste belastingaangifte en vermenigvuldigt dit bedrag vervolgens met twee om te komen tot de gewenste hoogte van de boete. 


\section{Mestafzetkosten per dier en per gebied}

De mestafzetkosten zijn berekend voor rundvee, varkens en pluimvee. Daarbij is onderscheid gemaakt in de afzetkosten per gebied (de concentratiegebieden Oost en Zuid en het niet-concentratiegebied Overig) (figuur 0 ).

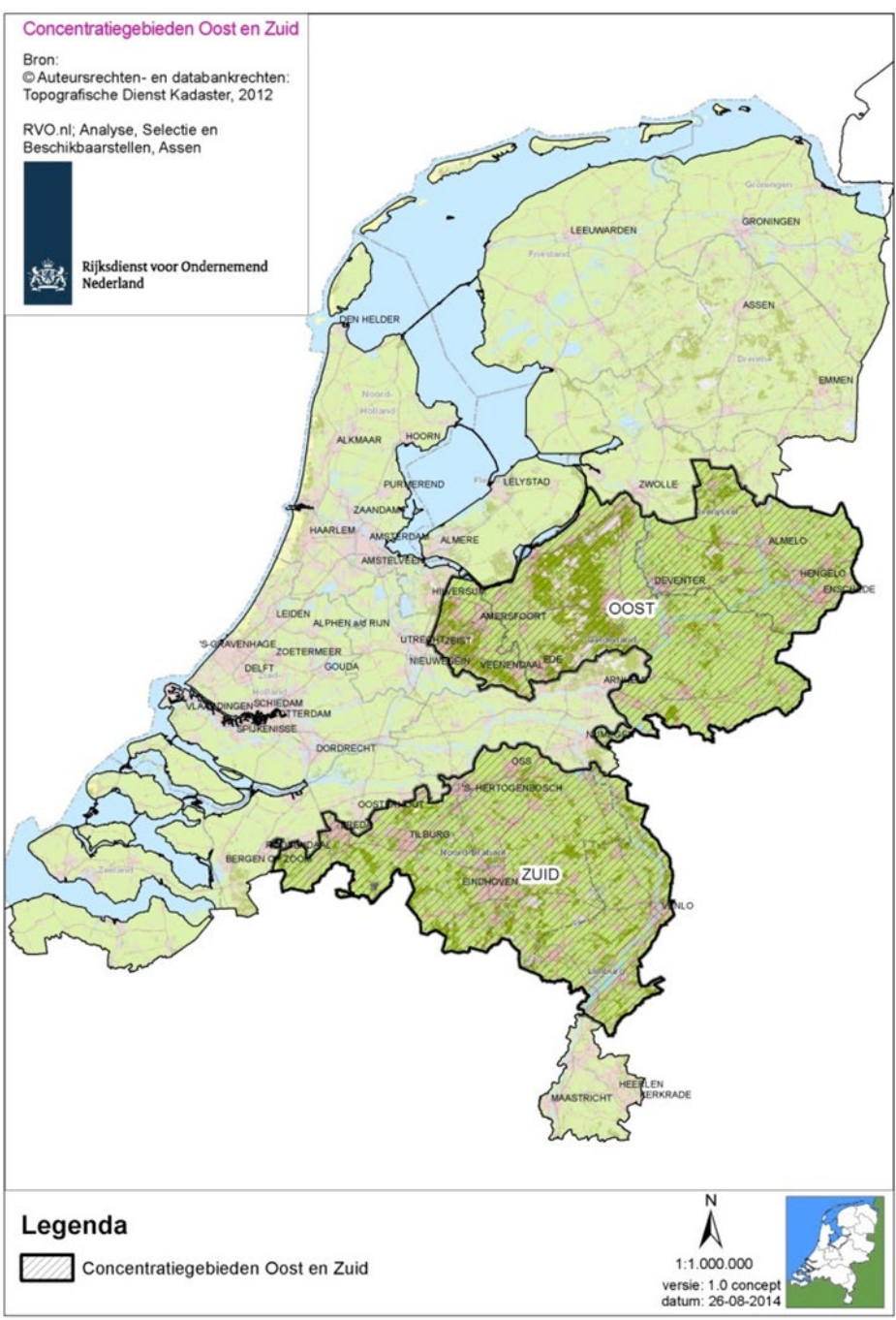

Figuur 0 De mestconcentratiegebieden in Nederland: Oost en Zuid (in figuur gearceerd) en het niet-concentratiegebied Overig (het niet gearceerde deel van Nederland)

De gemiddelde mestafzetkosten per bedrijf zijn in de afgelopen 7 jaar op melkvee- en varkensbedrijven gestaag toegenomen terwijl die op pluimveebedrijven iets zijn afgenomen. In het algemeen zijn de mestafzetkosten per bedrijf het hoogst in het concentratiegebied 'Zuid' en het laagst in het gebied 'Overig'. De gemiddelde mestafzetkosten verschillen sterk per sector en bedroegen in 2016 voor de melkveehouderij-, pluimveehouderij- en varkenshouderijbedrijven respectievelijk circa $6.000,11.000$ en 51.000 euro per bedrijf. 
x 1.000 euro per bedrijf

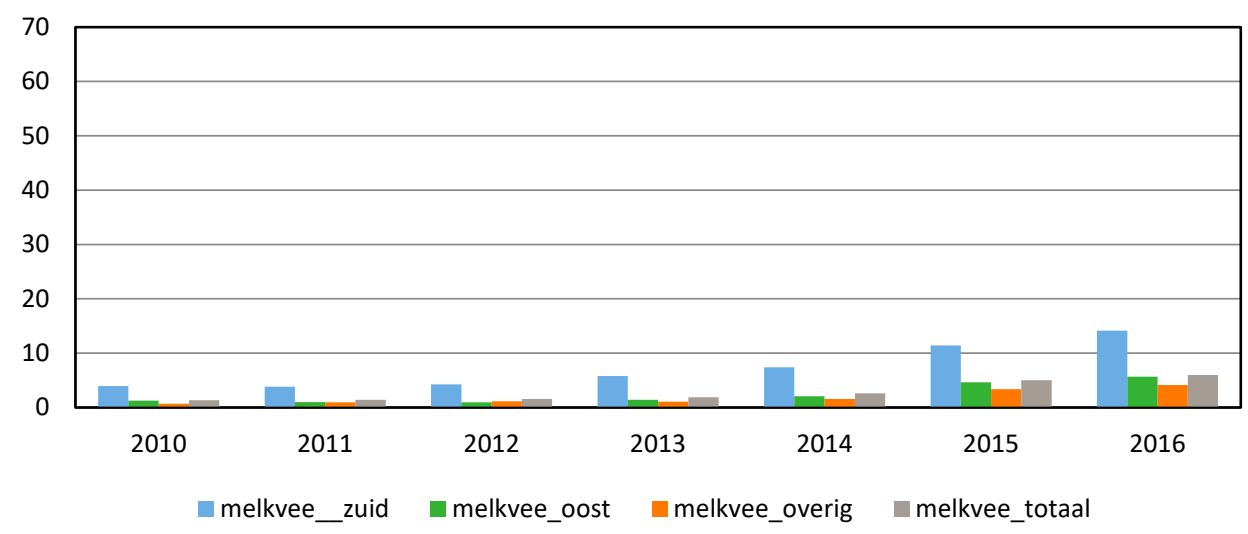

Figuur 1 Gemiddelde jaarlijkse mestafzetkosten in de melkveehouderij in de concentratiegebieden Zuid, Oost, Overig en totaal voor de jaren 2010 tot en met 2016

Bron: Bedrijveninformatienet Wageningen Economic Research.

x 1.000 euro per bedrijf

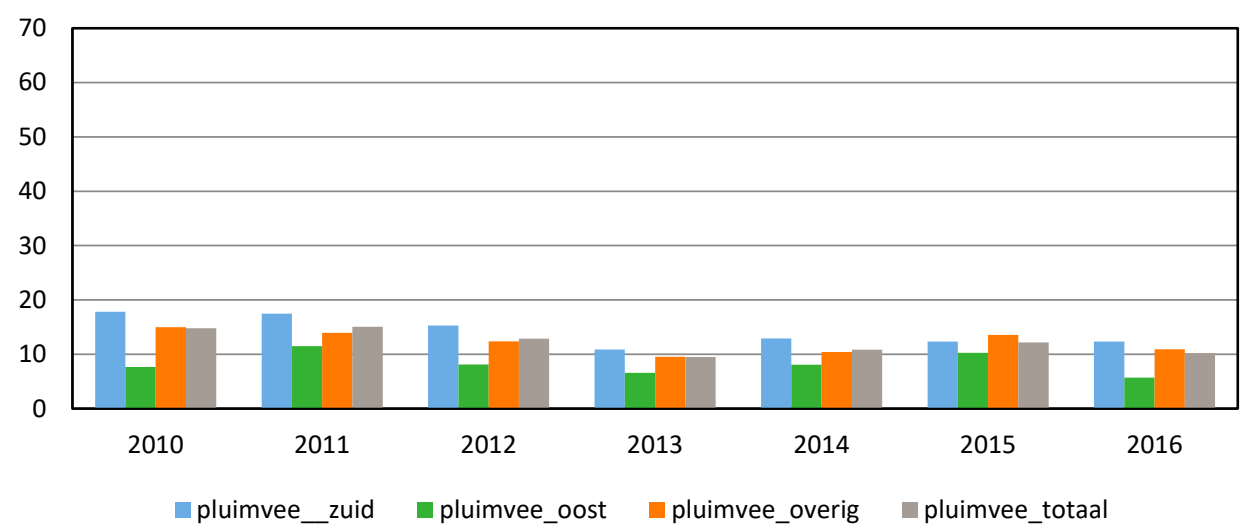

Figuur 2 Gemiddelde jaarlijkse mestafzetkosten in de pluimveehouderij in de concentratiegebieden Zuid, Oost, Overig en totaal voor de jaren 2010 tot en met 2016 Bron: Bedrijveninformatienet Wageningen Economic Research.

x 1.000 euro per bedrijf

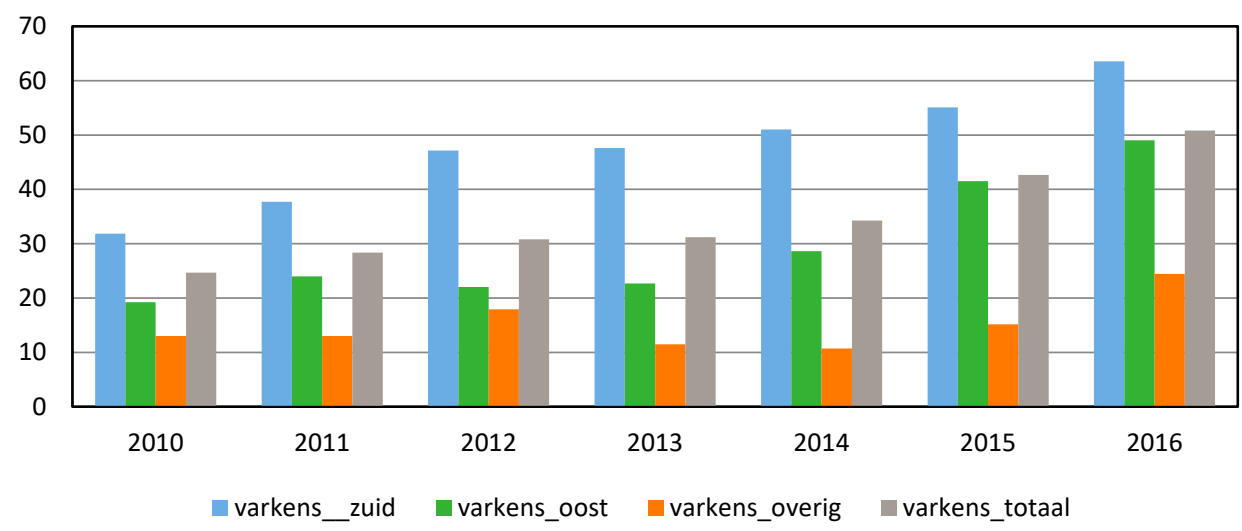

Figur 3 Gemiddelde jaarlijkse mestafzetkosten in de varkenshouderij in de concentratiegebieden Zuid, Oost, Overig en totaal voor de jaren 2010 tot en met 2016 Bron: Bedrijveninformatienet Wageningen Economic Research. 


\section{De minimale hoogte van boete voor overschrijding van de gebruiksnormen}

\subsection{Aanpak}

Ondernemers kunnen via het bestuursrecht worden beboet voor het overschrijden van de gebruiksnormen, niet kunnen verantwoorden van de dierlijke mest, niet voldoen aan de mestverwerkingsplicht en/of het niet voldoen aan verantwoorde groei melkveehouderij. Deze boete, zoals die momenteel in de mestwet is opgenomen, bedraagt 7 en 11 euro per kg voor respectievelijk stikstof en fosfaat $\left(\mathrm{P}_{2} \mathrm{O}_{5}\right)$. De vraag is in hoeverre de boete moet worden aangepast gegeven het uitgangspunt dat fraude niet lonend mag zijn en uitgaande van de formule:

Boete $>$ mestafzetkosten $\mathrm{x}$ fraude prikkel/ pakkans

Dit hoofdstuk beschrijft de stappen van de berekening en geeft de uitkomsten weer. Aansluitend wordt een analyse gegeven van de gehanteerde mestafzetkosten bij de oorspronkelijke berekening van de huidige boete.

\section{Mestafzetkosten}

De mestafzetkosten per ton mest zijn bekend. Deze kosten kunnen worden ontleend aan het Bedrijveninformatienet van Wageningen Economic Research. Voor het jaar 2016 bedroegen de mestafzetkosten voor rundvee-, pluimvee- en varkensmest respectievelijk circa 12, 11 en 20 euro per ton. De mestafzetkosten (euro/ton) voor pluimveemest zijn in de drie mestconcentratiegebieden gelijk. Voor de afzet van varkensmest en rundveemest zijn er wel verschillen in kosten in de onderscheiden gebieden. Zo zijn de mestafzetkosten voor rundveemest in de concentratiegebieden Zuid en Oost $17 \%$ hoger en in Overig $17 \%$ lager dan de gemiddelde mestafzetkosten in Nederland. De mestafzetkosten voor varkensmest zijn in de gebieden Zuid en Overig respectievelijk 5 en $20 \%$ lager en in Oost $10 \%$ hoger dan de gemiddelde mestafzetkosten in Nederland (figuur 4).

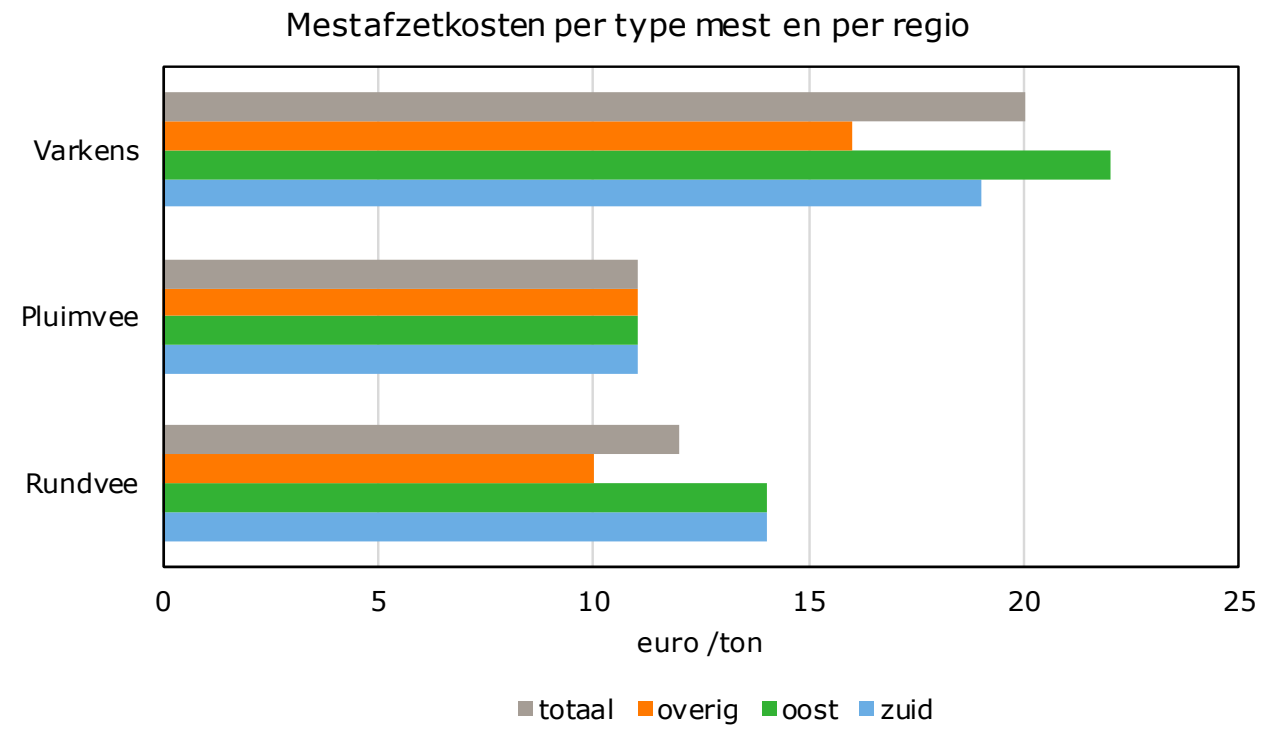

Figuur 4 De mestafzetkosten (euro/ton) per mestsoort voor de onderscheiden concentratiegebieden en voor geheel Nederland voor het jaar 2016 Bron: Bedrijveninformatienet Wageningen Economic Research. 
Voor het berekenen van de minimaal benodigde boete per $\mathrm{kg} \mathrm{N}$ en per $\mathrm{kg} \mathrm{P}_{2} \mathrm{O}_{5}$ zijn de mestafzetkosten per ton mest omgerekend naar de mestafzetkosten per $\mathrm{kg} \mathrm{N}$ en $\mathrm{P}_{2} \mathrm{O}_{5}$ op basis van de forfaitaire gehalten in mest (RVO.nl, 2018) (tabel 1).

Tabel 1 De forfaitaire gehalten van stikstof en fosfaat ( $\mathrm{kg} / \mathrm{ton}$ ) per mesttype

\begin{tabular}{lrrr} 
Type mest & Mestcode & $\mathrm{N}(\mathrm{kg} / \mathrm{ton})$ & $\mathrm{P}_{2} \mathbf{0}_{5}(\mathrm{~kg} /$ ton \\
Rundvee & 14 & 4,0 & 1,5 \\
\hline Pluimvee & 35 & 27 & 25 \\
\hline Varkens & 50 & 6,4 & 3,8 \\
\hline
\end{tabular}

Bron: RVO.nl, 2018.

De huidige boete bedraagt 7 en 11 euro per kg voor respectievelijk stikstof en fosfaat (P205). Bij de berekening van de minimaal benodigde hoogte van de boetes voor stikstof en fosfaat is van dezelfde verhouding uitgegaan. Het is denkbaar om de kosten alleen aan fosfaat toe te rekenen. In de praktijk worden de kosten voor de mestafzet veelal volledig toegerekend aan fosfaat omdat in de regelgeving de fosfaatgebruiksnormen voor de afzet van dierlijke mest beperkend zijn. In dat geval zou de benodigde boete voor stikstof 0 euro per $\mathrm{kg} \mathrm{N}$ zijn. Ook voor deze kostenverhouding is de benodigde hoogte van de boete uitgerekend. Tevens is de minimaal benodigde hoogte van de boete uitgerekend voor een tussenliggende optie waarbij de kosten voor stikstof en fosfaat worden verdeeld op basis van $1: 3$.

\section{Pakkans}

De pakkans wordt gedefinieerd als het aandeel nutriënten waarvan is aangetoond dat de gebruiksnormen zijn overschreden ten opzichte van de totale omvang van de overschrijding van de gebruiksnormen. De pakkans kan in theorie lopen van 0 (wordt nooit gepakt) tot 100\% (altijd gepakt). Allereerst is de benodigde boete berekend in het geval dat de pakkans $100 \%$ bedraagt.

Omdat deze in de praktijk veel lager is, is de mogelijk benodigde hoogte van de boete ook berekend voor kleine pakkansen. Hoe de pakkans in werkelijkheid is, is niet bekend aangezien onbekend is hoeveel mest in totaal onjuist wordt afgezet. Wel bekend is dat $0,1 \%$ van de transporten fysiek wordt gecontroleerd (Velthof et al., 2017). Bij controle zijn er echter mogelijkheden om ondanks fraude niet gepakt te worden. Voorbeelden daarvan zijn genoemd in interviews:

1. Bij frauduleuze transporten heeft de chauffeur twee laadbonnen bij zich. Bij controle laat hij de juiste zien en wordt de juiste bon voor de verdere administratieve afhandeling gebruikt. Als er geen controle heeft plaatsgevonden, wordt de foutieve bon gebruikt voor de verdere administratieve afhandeling.

2. Een transporteur/veehouder wordt op heterdaad betrapt bij mest uitrijden op het land van de buurman zonder Vervoersbewijs Dierlijke Mest. De veehouder en de buurman gaan na het incident bij elkaar zitten en regelen dat de grond van de buurman door de veehouder is gehuurd of gepacht.

Wel is het zo dat achteraf ook administratief fraude kan worden ontdekt. Echter, in de interviews (De Koeijer et al., 2018) gaven de respondenten ook aan dat als je fraude wilt plegen je in ieder geval zorgt dat de boekhouding klopt en zo op papier voldoet aan de administratieve verplichtingen dan wel het overschrijden van de gebruiksnormen. Omdat de analyses voor de handhaving van mest grotendeels gebaseerd zijn op boekhoudkundige data is daarom voor deze analyse ook uitgegaan van een pakkans die mogelijk tussen de 0,1 en $1 \%$ ligt. Het effect van een pakkans tussen de 0,1 en $1 \%$ op de minimaal benodigde hoogte van de boete is grafisch in beeld gebracht voor dit traject (paragraaf 4.3).

Indien de pakkans groter is en bijvoorbeeld 5 of $10 \%$ bedraagt, zou de minimaal benodigde hoogte van de boete zoals berekend bij een pakkans van 100\% en een fraudeprikkel van één respectievelijk 20 en 10 keer zo hoog zijn. 


\section{Fraudeprikkel}

De fraudeprikkel geeft aan in hoeverre een ondernemer geneigd is tot fraude. Indien uitgegaan wordt van een puur economisch rationeel handelende ondernemer is de fraudeprikkel gelijk aan één. In dit geval weegt een mogelijk verlies (indien hij beboet wordt) even zwaar als een potentieel gewin als gevolg van fraude. Vanuit de nutsfunctietheorie geldt dat een mogelijk verlies (boete) zwaarder weegt dan een extra gewin (vermijden van mestafzetkosten door fraude). De fraudeprikkel zal over het algemeen kleiner zijn dan één. Uit onderzoek blijkt dat men vindt het erger om een verlies te hebben dan datzelfde bedrag als winst te kunnen realiseren. Omdat dit verschil ook weer niet zo groot is dat het nut van een mogelijk verlies gelijk staat aan bijvoorbeeld de helft van het mogelijke gewin zal het wel dicht bij één liggen (Oude Lansink, 2018). In welke mate de fraudeprikkel kleiner is hangt af van de mate van risico-aversie van de ondernemer.

Aan de andere kant is het niet uitgesloten dat de fraudeprikkel groter is dan één. Zo kunnen er bijvoorbeeld situaties zijn waarin een ondernemer niets te verliezen heeft omdat hij zonder frauderen sowieso failliet zou kunnen gaan. Een boete leidt in die situatie niet tot een lager nut. De fraudeprikkel kan in dit soort extreme situaties daarom groter zijn dan één omdat zonder fraude in deze situatie het bedrijf sowieso failliet zou gaan.

Op basis van bovenstaande overwegingen is het effect van een fraudeprikkel die afwijkt van één op de minimaal benodigde hoogte van de boete grafisch in beeld gebracht voor het traject gaande van 0,6 tot 1,4 voor de fraudeprikkel in de figuren 7 tot en met 10 (par. 4.3).

\subsection{Berekeningswijze van de hoogte van de boete}

Per bedrijfstype en per mestconcentratiegebied, en gegeven de mestafzetprijs voor stikstof en fosfaat, is de minimaal benodigde hoogte van de boete voor onjuist afgezette mest berekend voor de drie onderscheiden kostenverhoudingen voor stikstof en fosfaat.

Voor de berekening van de nieuwe minimaal benodigde boeteprijs voor $1 \mathrm{~kg}$ stikstof, waarbij de verhouding in de boeteprijs voor stikstof en fosfaat gelijk blijft aan de huidige (namelijk $7: 11$ ), kan deze als volgt worden berekend:

$\mathrm{B}_{\mathrm{Nt}+1}=\mathrm{B}_{\mathrm{Nt}} *\left(\mathrm{~K} / \mathrm{B}_{\mathrm{t}}\right)$

Waarin:

$\mathrm{B}_{\mathrm{Nt}+1}=$ Nieuwe minimaal benodigde boete; euro per $\mathrm{kg} \mathrm{N}$

$\mathrm{B}_{\mathrm{Nt}}=$ Huidige boete; euro per $\mathrm{kg} \mathrm{N}$

$\mathrm{K}=$ huidige mestafzetkosten, euro per ton mest

$\mathrm{B}_{\mathrm{t}}=$ huidige boete, euro per ton mest

$B_{t}=B_{n t} * f_{n}+B_{p t} * f_{p}$

Waarin:

$\mathrm{f}_{\mathrm{n}}=$ fractie $\mathrm{N}$ in ton mest, $\mathrm{kg} \mathrm{N}$ per ton mest

$\mathrm{f}_{\mathrm{p}}=$ fractie $\mathrm{P}_{2} \mathrm{O}_{5}$ in mest, $\mathrm{kg} \mathrm{P}_{2} \mathrm{O}_{5}$ per ton mest

$\mathrm{B}_{\mathrm{pt}}=$ huidige boete, euro per $\mathrm{kg} \mathrm{N}$

$\mathrm{B}_{\mathrm{pt}}=$ huidige boete, euro per $\mathrm{kg} \mathrm{P}_{2} \mathrm{O}_{5}$

Voor de berekening van de nieuwe minimaal benodigde boeteprijs voor fosfaat (euro/kg $\mathrm{P}_{2} \mathrm{O}_{5}$ ) geldt dan:

$\mathrm{B}_{\mathrm{Pt}+1}=\mathrm{B}_{\mathrm{Pt}} *\left(\mathrm{~K} / \mathrm{B}_{\mathrm{t}}\right)$

Bij de verhouding 1:3 voor de prijsverhouding van stikstof en fosfaat geldt dezelfde procedure.

Aangezien de prijsverhouding tussen de boete voor stikstof en fosfaat gelijk blijft kan voor $B_{\text {nt }}$ en voor $\mathrm{B}_{\mathrm{pt}}$ de prijs van 1 en respectievelijk 3 worden aangehouden. 
Indien alleen een boete wordt toegerekend aan fosfaat kan de minimaal benodigde boete voor $1 \mathrm{~kg}$ fosfaat berekend worden als:

$B_{p t+1}=K / f_{p}$

\subsection{Uitkomsten van de berekende boetes}

De minimaal benodigde hoogte van de boete voor stikstof $(\mathrm{N})$ en fosfaat $\left(\mathrm{P}_{2} \mathrm{O}_{5}\right)$ uitgaande van een prijsverhouding van de boete voor stikstof en fosfaat van achtereenvolgens $7: 11,1: 3$ en $0: 1$ is weergeven in de figuren 5 en 6 voor stikstof en fosfaat. Uitgaande van een fraudeprikkel gelijk aan één en een pakkans van $100 \%$ en de mestafzetprijzen van 2016 en de prijsverhouding van stikstof : fosfaat van $7: 11$, bedraagt de minimaal benodigde boete voor stikstof 1,$9 ; 0,2$ en 1,6 euro per kg $\mathrm{N}$ voor respectievelijk rundveemest, pluimveemest en varkensmest. Voor fosfaat bedraagt deze 2,9;0,3 en 2,5 euro per $\mathrm{kg} \mathrm{P}_{2} \mathrm{O}_{5}$.

Bij een prijsverhouding voor stikstof en fosfaat van 7:11 ligt de minimale hoogte van de boete per $\mathrm{kg}$ stikstof en fosfaat voor varkensmest en rundveemest dichter bij elkaar dan wanneer wordt uitgegaan van een verhouding 1:3 of 0:1. Ook geven de figuren aan dat de minimaal benodigde hoogte van de boete in het geval van pluimveemest een factor 10 of meer lager is dan die voor varkens- en rundveemest. Aangezien de verschillen in mestafzetprijzen (euro/ton) per ton mest tussen de onderscheiden mestafzetgebieden relatief klein waren (figuur 4) zijn de berekende minimale hoogtes van de boete in de figuren 5 en 6 niet uitgesplitst naar mestconcentratiegebied. Deze data is wel weergegeven in bijlage 1 .

De resultaten geven aan dat de berekende minimaal benodigde hoogte van de boetes voor varkensmest en rundveemest hoger zijn dan die voor pluimveemest, volgens de hier toegepaste berekeningswijze. Voor pluimveemest is de berekende minimaal benodigde boete relatief laag omdat pluimveemest relatief hoge gehalten aan stikstof en fosfaat heeft (tabel 1).

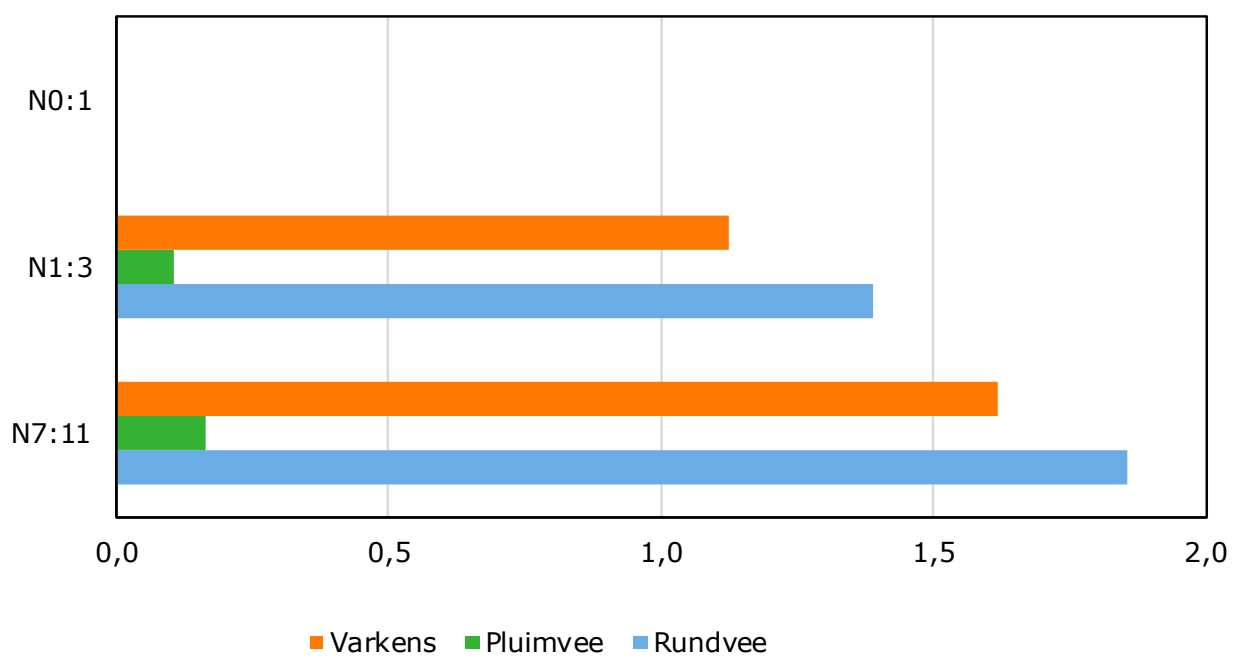

Figuur $5 \quad$ Minimale hoogte boete (euro/kg) voor stikstof ( $N$ ) in mest (euro per $\mathrm{kg} N$ ), bij prijsverhoudingen van stikstof : fosfaat van $7: 11 ; 1: 3$ en $0: 1$. Resultaten zijn gebaseerd op de mestafzetprijzen van 2016, en de aannames dat pakkans=1 en fraudeprikkel=1 


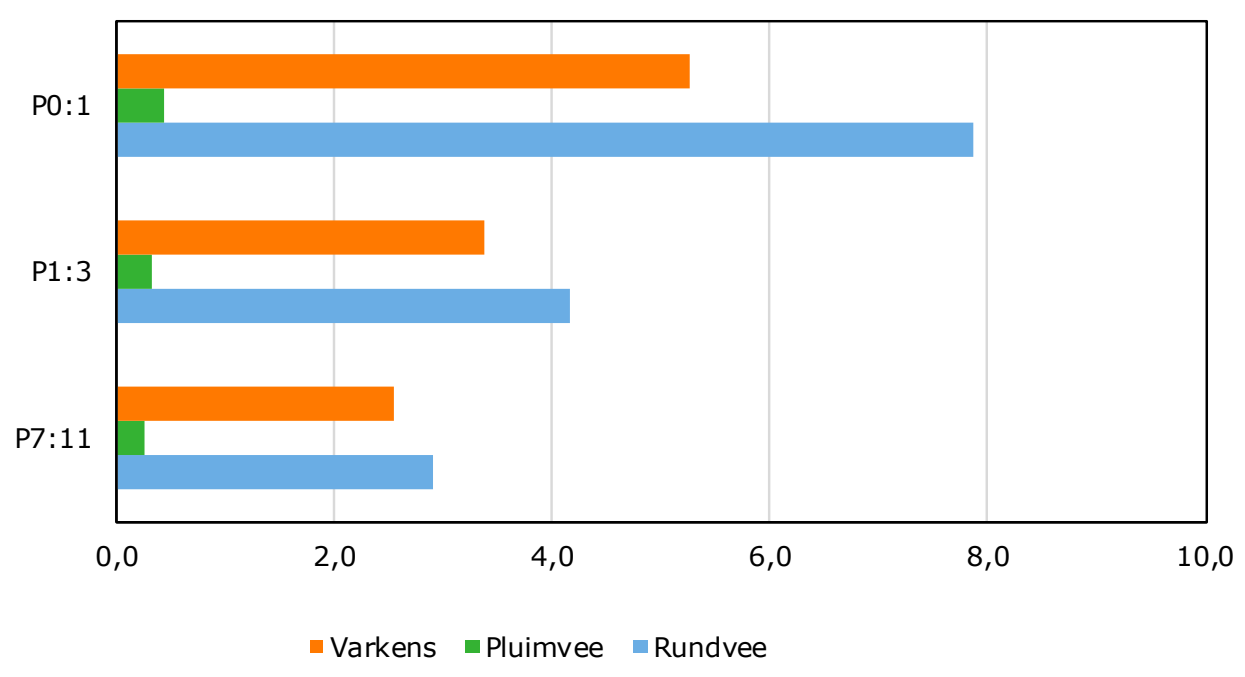

Figuur 6 Minimale hoogte boete (euro/kg) voor fosfaat $\left(\mathrm{P}_{2} \mathrm{O}_{5}\right)$ onderscheiden per prijsverhouding stikstof : fosfaat van 7:11; 1:3 en 0:1 op basis van de mestafzetprijzen van 2016 bij pakkans=1 en fraudeprikkel=1

\section{Pakkans en fraudeprikkel niet gelijk aan één}

In de voorgaande berekening was aangenomen dat de pakkans $100 \%$ is en de fraudeprikkel gelijk is aan één. Indien de pakkans kleiner is dan $100 \%$, zou er zonder aanpassing van de boete een netto economisch voordeel zijn voor de fraudeur. Om dit te voorkomen moet de minimale hoogte van de boete omgekeerd evenredig zijn met de pakkans. Als 1 op de 10 fraudeurs wordt gepakt en de pakkans dus $10 \%$ bedraagt, moet de boete 10 keer zo hoog zijn om te voorkomen dat fraude rendabel is. Bij de inschatting dat de pakkans 1 op de 20 bedraagt, moeten de boetes dan 20 keer zo hoog worden als is aangegeven in de figuren 5 en 6.

Indien de fraudeprikkel kleiner is dan één zoals is afgeleid op basis van de nutstheorie (Oude Lansink, 2018) en uitgaande van economisch rationeel handelen dan wel in extreme situaties zoals een dreigend faillissement groter is dan één, dan moet de berekende boete worden gecorrigeerd voor deze prikkel door deze hiermee te vermenigvuldigen.

In de figuren 7 en 9 is het effect van een pakkans oplopend van 0,1 tot $1 \%$ op de minimaal benodigde hoogte van de boete voor stikstof (euro/kg N) en fosfaat (euro/kg $\mathrm{P}_{2} \mathrm{O}_{5}$ ) weergegeven uitgaande van een fraudeprikkel gelijk aan één en de prijsverhouding voor de boete van 7:11. Met behulp van de stippellijnen is eveneens het effect weergegeven indien de fraudeprikkel varieert tussen 0,6 en 1,4. In bijlage 2 zijn de bijbehorende data in tabelvorm weergegeven. De minimaal benodigde boete voor stikstof en fosfaat voor de prijsverhoudingen van stikstof en fosfaat van 1:3 en 0:1 zijn niet in figuren weergegeven maar zijn in bijlage 2 wel in tabellen weergegeven.

Omdat in de figuren 7 en 9 bij de pakkans gaande van 0,7 tot 1\% de lijnen erg dicht bij elkaar liggen, is in de figuren 8 en 10 de minimaal benodigde boete tevens apart uitgelicht voor de pakkans gaande van 0,7 tot $1 \%$ voor respectievelijk stikstof en fosfaat.

Zoals de figuren 7, 8, 9 en 10 laten zien worden bij pakkansen kleiner dan $1 \%$ de boetes zoals berekend bij $100 \%$ pakkans met een factor 100 tot 1.000 groter. Hierdoor variëren de boetes van 190; 20 en 160 euro per kg N voor respectievelijk rundveemest, pluimveemest en varkensmest. Voor fosfaat bedraagt deze 290; 30 en 250 euro per $\mathrm{kg} \mathrm{P}_{2} \mathrm{O}_{5}$. Bij een kans van 0,1\% zouden de boetes nog weer een factor 10 hoger moeten zijn. Ook laten de figuren zien dat de omvang van de fraudeprikkel die over het algemeen dicht bij één ligt weinig invloed heeft op de berekende minimaal benodigde boete. 
Boete bij verschillende pakkansen

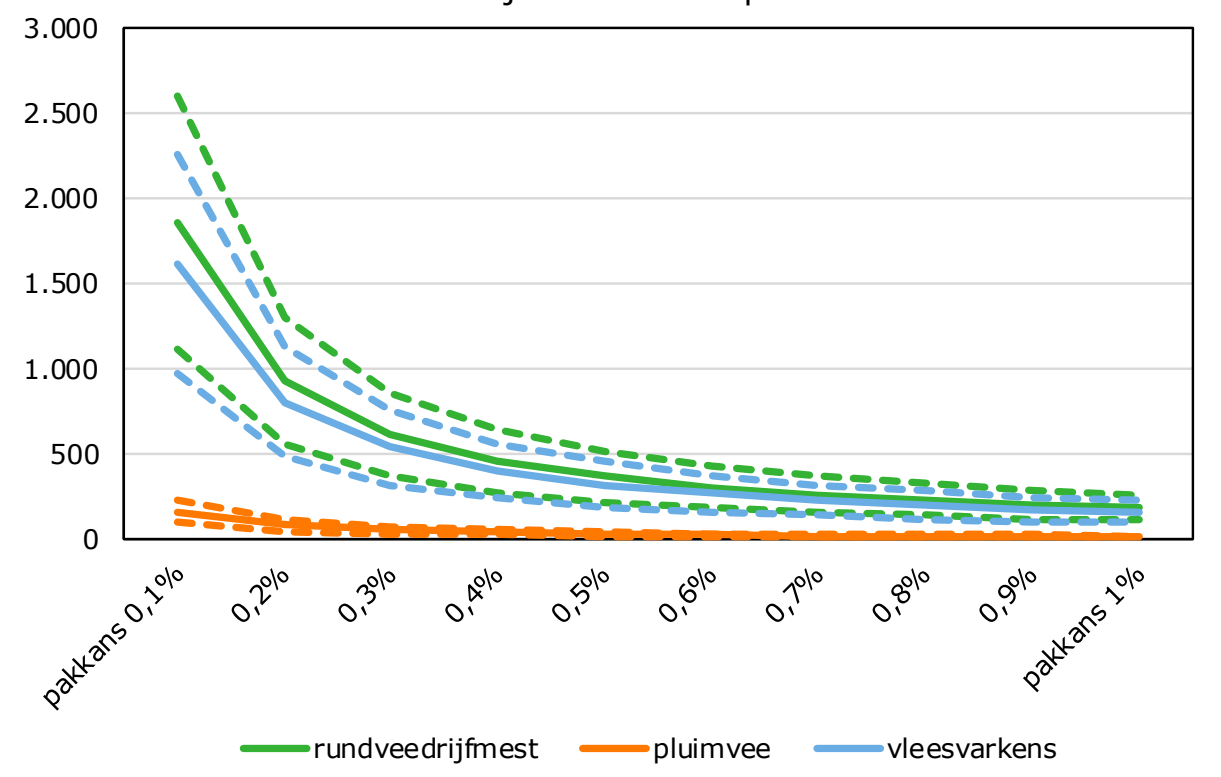

Figuur 7 Minimale hoogte boete voor stikstof (euro $/ \mathrm{kg} \mathrm{N}$ ) op basis van de gemiddelde mestafzetprijzen van 2016 in Nederland bij een pakkans die oploopt van 0,1 tot 1\% bij fraudeprikkel=1 uitgaande van de prijsverhouding stikstof : fosfaat van 7:11. De gestippelde lijnen geven het effect weer indien de fraudeprikkel 0,6 (onderste lijn) en 1,4 (bovenste lijn) is

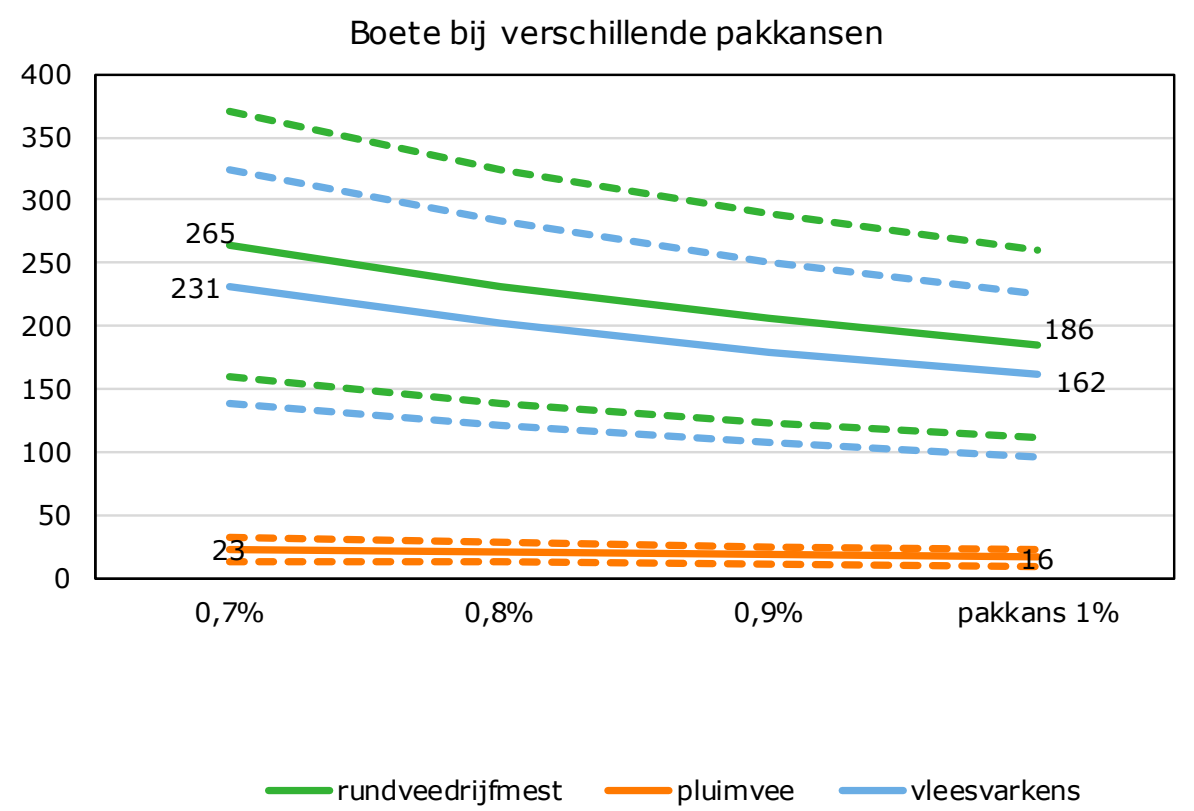

Figuur 8 (Uitvergroting van figuur 7) Minimale hoogte boete voor stikstof (euro/kg $\mathrm{N}$ ) op basis van de gemiddelde mestafzetprijzen van 2016 in Nederland bij een pakkans die oploopt van 0,7 tot $1 \%$ bij fraudeprikkel=1 uitgaande van de prijsverhouding stikstof : fosfaat van 7:11. De gestippelde lijnen geven het effect indien de fraudeprikkel 0,6 (onderste lijn) en 1,4 (bovenste lijn) is 
Boete bij verschillende pakkansen

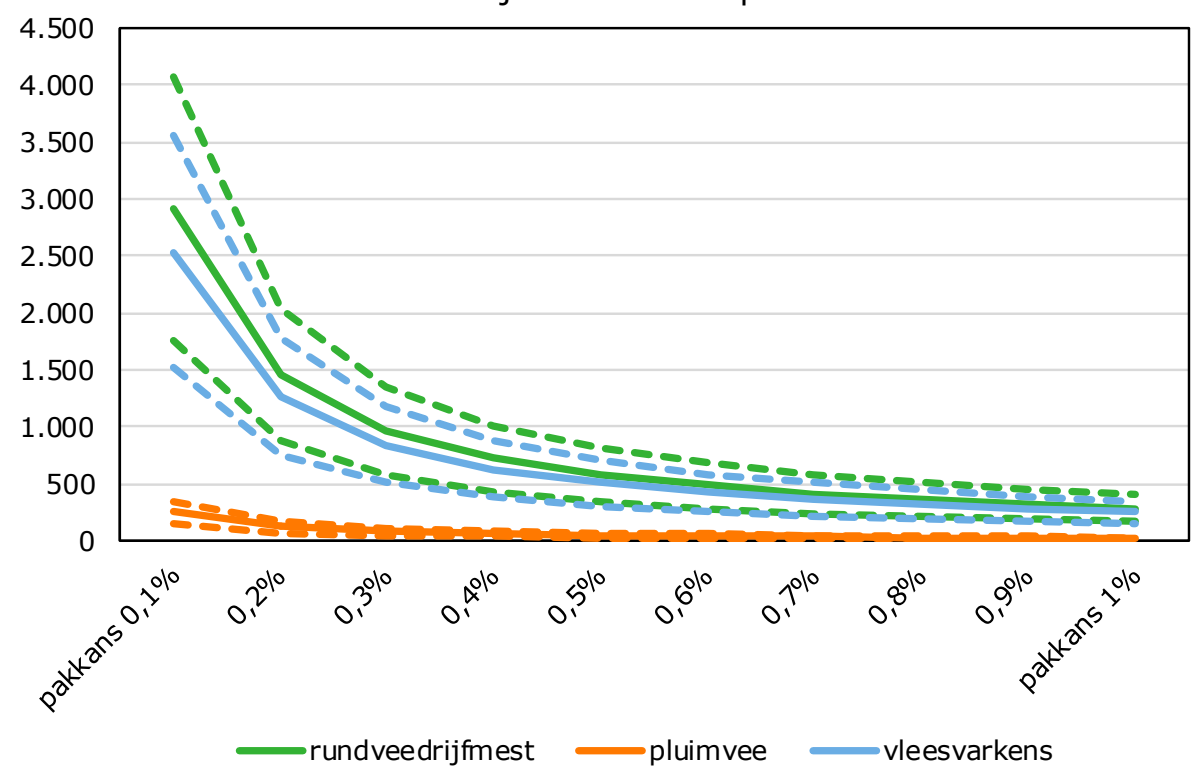

Figuur 9 Minimale hoogte boete voor fosfaat (euro/kg $\mathrm{P}_{2} \mathrm{O}_{5}$ ) op basis van de gemiddelde mestafzetprijzen van 2016 in Nederland bij een pakkans die oploopt van 0,1 tot 1\% bij fraudeprikkel=1 uitgaande van de prijsverhouding stikstof : fosfaat van 7:11. De gestippelde lijnen geven het effect indien de fraudeprikkel 0,6 (onderste lijn) en 1,4 (bovenste lijn) is

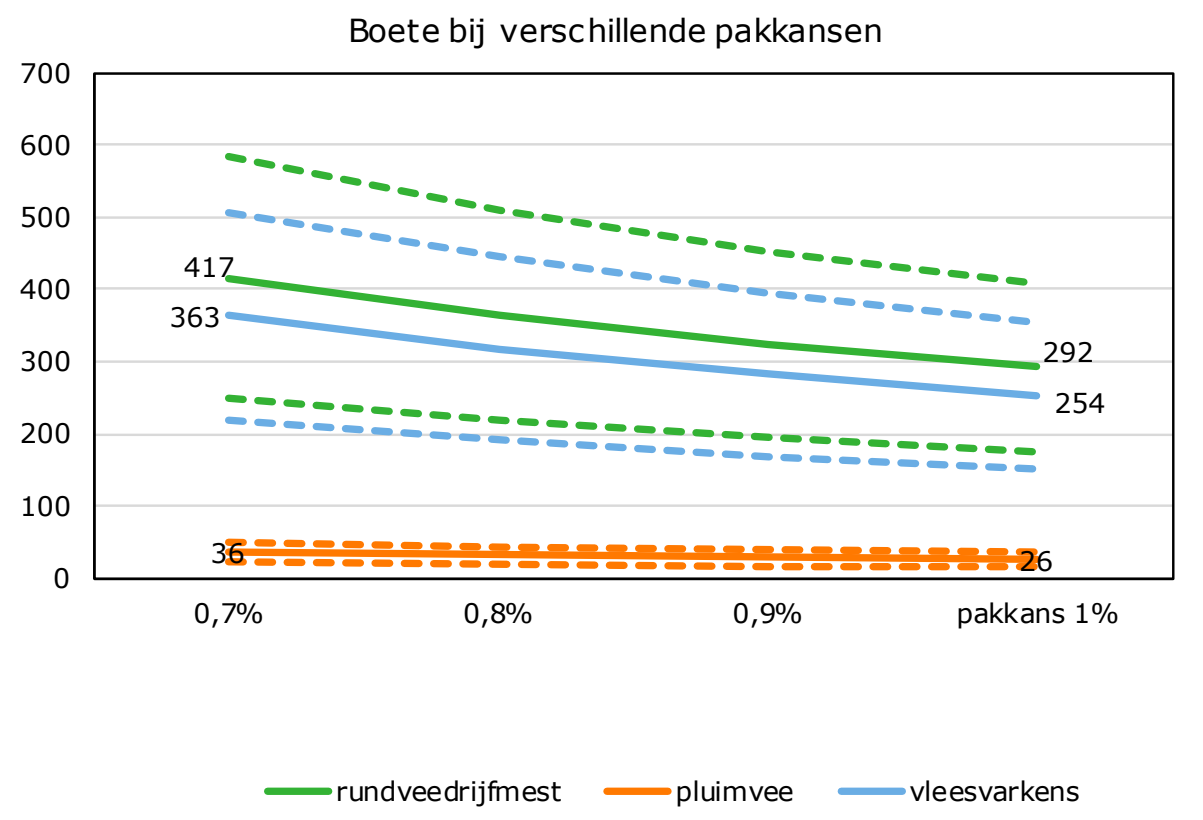

Figuur 10 (Uitvergroting figuur 9) Minimale hoogte boete voor fosfaat (euro/kg $\mathrm{P}_{2} \mathrm{O}_{5}$ ) op basis van de gemiddelde mestafzetprijzen van 2016 in Nederland bij een pakkans die oploopt van 0,7 tot 1\% bij fraudeprikkel=1 uitgaande van de prijsverhouding stikstof : fosfaat van 7:11. De gestippelde lijnen geven het effect weer indien de fraudeprikkel 0,6 (onderste lijn) en 1,4 (bovenste lijn) is 


\subsection{Vaststelling huidige boete voor overschrijding van de gebruiksnormen}

Uitgaande van de in 2005 vastgestelde boetes van 7 en 11 euro per kg voor respectievelijk stikstof en fosfaat en de door de Auditdienst (2018) beschreven gehanteerde methodiek kan berekend worden of basis van de huidige mestafzetkosten de boetes zouden moeten worden bijgesteld. De methodiek is gebaseerd op het vermoede economisch voordeel waarbij de wetgever destijds is uitgegaan van de verwachte kosten voor de afzet van mest over langere afstand waarbij dit bedrag forfaitair is bepaald als het gemiddelde van deze kosten voor mestproducenten van verschillende soorten mest (graasdier, varkens-, pluimveemest etc.). Het bestraffende deel bedroeg daarbij $100 \%$ van het forfaitair bepaalde economisch voordeel (Auditdienst, 2018). Dit betekent dat de totale boetekosten voor een kilo mest waarvoor de gebruiksnormen werden overschreden op basis van de destijds vastgestelde boeteprijzen van 7 en 11 euro per kg voor stikstof en fosfaat gelijk is aan het economisch voordeel op basis van de verwachte mestafzetkosten en het punitieve deel eveneens gelijk aan de verwachte mestafzetkosten.

De totale boeteprijs per kg rundvee-, pluimvee- en varkensmest voor het niet voldoen aan de gebruiksnormen kan berekend worden op basis van de forfaitaire gehalten van stikstof en fosfaat in rundvee- varkens- en pluimveemest (tabel 1) te vermenigvuldigen met de boeteprijzen voor stikstof en fosfaat. Vervolgens is de uitkomst gedeeld door twee aangezien de helft van het boetebedrag bestaat uit het wederrechtelijk verkregen economisch voordeel door het niet maken van de mestafzetkosten en de andere helft het bestraffende element is (Auditdienst, 2018). Op basis van deze uitgangspunten zouden de mestafzetkosten voor rundvee-, varkens- en pluimveemest respectievelijk 22, 43 en 261 euro per ton mogen bedragen voordat de boetes naar boven zouden moeten worden bijgesteld.

Zoals aangegeven in figuur 4 bedroegen in 2016 de gemiddelde mestafzetkosten voor rundvee-, varkens en pluimveemest respectievelijk circa 12, 20 en 11 euro per ton. Dit is aanzienlijk lager dan de mestafzetkosten zoals deze zijn afgeleid uit de gehanteerde uitgangspunten voor de berekening van de huidige boetes. Dit betekent dat er vooralsnog geen reden is om de huidige boetes naar boven bij te stellen. De afzetkosten voor rundvee- en varkensmest zijn een factor twee lager terwijl die voor pluimveemest een factor 20 lager liggen. Deze bevinding sluit aan bij de in de workshop verwoorde mening dat de huidige boetes voor overschrijding van de gebruiksnormen voldoen en niet naar boven hoeven te worden bijgesteld om afschrikwekkend te zijn. 


\section{$5.1 \quad$ Algemene discussie}

\section{Omvang pakkans}

De berekening van de minimaal benodigde boete per kilo stikstof of fosfaat bij overschrijding van de gebruiksnormen is gebaseerd op de mestafzetkosten, de pakkans en de fraudeprikkel. Voor de berekening maakt het erg veel uit welke aannames worden gedaan over de pakkans aangezien de minimaal benodigde hoogte van de boete omgekeerd evenredig is aan de pakkans. Indien de hoogte van de boete gebaseerd wordt op de in deze analyse gehanteerde formule verdient het aanbeveling om meer inzicht te krijgen in de werkelijke pakkans.

\section{Omvang fraudeprikkel}

Ook over de omvang van de fraudeprikkel is weinig zekerheid. Maar de verwachting is dat deze globaal net iets kleiner is dan één, uitgaande van economisch rationaal handelend persoon. Deze analyse is puur gebaseerd op rationeel economisch handelen. In de praktijk speelt ook de moraal een rol. Veel personen zullen niet willen frauderen omdat dit niet past binnen hun normen en waarden. Afhankelijk van de sterkte van die waarden en normen zou de fraudeprikkel tussen nul en één liggen en mogelijk aanzienlijk kleiner zijn dan de minimale waarde van 0,6 die in deze analyse was meegenomen. Bij dergelijk kleine fraudeprikkels zou het relatieve effect hiervan op de minimaal benodigde boete groter worden dan in de huidige berekeningen.

In de huidige berekeningen waarbij is uitgegaan van een fraudeprikkel van 0,6 tot 1,4 maakt het in relatie tot de in de analyse aangenomen kleine pakkans niet zoveel uit welke aanname hierover gemaakt is. De fraudeprikkel heeft in vergelijking met het effect van de pakkans een relatief kleine invloed op de berekende minimaal benodigde hoogte van de boete.

\section{Implicatie berekende boeteprijs bij overschrijding gebruiksnormen}

Indien de pakkans zo klein is als in dit rapport is aangenomen, wordt een ondernemer indien hij de in dit rapport berekende boetes krijgt opgelegd, zeer hard getroffen. De boete staat in dat geval niet in verhouding tot het mogelijk genoten economische voordeel van mest die onjuist is afgezet en/of geregistreerd. Een probleem hierbij is namelijk dat dit op de langere termijn niet uit middelt. Bij een boete gebaseerd op een dergelijk kleine pakkans wordt dan in feite het totale economische voordeel van de fraudeurs op een klein deel van de groep verhaald. In dat geval is de hoogte van de boete die gebaseerd is op een dergelijk kleine kans, mogelijk niet proportioneel en dus aanvechtbaar. Dit betekent dat bij dergelijk kleine pakkansen de gehanteerde formule voor het berekenen van de minimaal benodigde boete waarschijnlijk niet adequaat is. Indien de pakkansen kunnen worden vergroot, zouden hierdoor de minimaal benodigde boetes aanzienlijk kleiner kunnen worden. Echter, om hier meer over te kunnen zeggen is allereerst meer inzicht nodig in de daadwerkelijke pakkans ten aanzien van onjuist afgezette mest.

\section{Verhouding hoogte boete voor stikstof en fosfaat}

Voor de berekening van de benodigde hoogte van de boete voor het overschrijden van de gebruiksnormen is gerekend met drie prijsverhoudingen namelijk de huidige verhouding van 7:11 voor stikstof en fosfaat, $1: 3$ en $0: 1$. Wat betreft de laatste verhouding zou de volledige boete worden toegerekend aan fosfaat. In dat geval kan niet meer beboet worden voor het overschrijden van de stikstofgebruiksnorm en de norm voor dierlijke mest. In het kader van de Europese Nitraatrichtlijn moet wel aan deze gebruiksnormen worden voldaan. Dit betekent dat boetes op basis van deze verhouding geen optie zijn.

In hoeverre de boetes al dan niet proportioneel zijn, hangt ook sterk af van de vraag over welk deel van de mestafvoer een eventuele boete wordt opgelegd. Zou een boete alleen worden opgelegd voor de omvang van één transport, nadat is geconstateerd dat de mestboekhouding niet klopt op basis van 
de controle van één mesttransport en dat dus de gebruiksnormen zijn overschreden, dan weegt dit voor grote bedrijven aanzienlijk minder zwaar dan voor kleinere bedrijven. Zo hebben de kleinere vleesvarkensbedrijven circa 18 mesttransporten per jaar en de grote circa 10 keer zo veel (zie kader). Uitgaande van een pakkans van één procent en bij $100 \%$ fraude ten aanzien van het transport bedraagt de boete dan 69.000 euro. In veel gevallen zal de fraude niet de volledige mestproductie betreffen die onjuist is afgezet maar zal een deel daarvan onjuist zijn afgezet.

\section{Aantal transporten op $\mathbf{2 0 \%}$ kleinste vleesvarkensbedrijven}

In 2016 hebben de $20 \%$ kleinste vleesvarkensbedrijven gemiddeld 720 vleesvarkens. Deze produceren globaal 720 ton mest. Hiervan blijft gemiddeld 100 ton op het eigen bedrijf en wordt dus 620 ton afgevoerd. Uitgaande van 35 ton per vracht betekent dit dat er op deze bedrijven gemiddeld ongeveer 18 transporten per jaar zijn.

\section{Aantal transporten op $\mathbf{2 0 \%}$ grootste vleesvarkensbedrijven}

De $20 \%$ grootste vleesvarkensbedrijven hebben in 2016 gemiddeld 6.600 vleesvarkens. Deze produceren globaal 6600 ton mest waarvan gemiddeld 100 ton op het eigen bedrijf wordt geplaatst. Er moet dan 6.500 ton mest worden afgevoerd. Voor de afvoer hiervan zijn gemiddeld 186 transporten per jaar nodig.

\section{Omvang boete per transport}

De minimale boete per transport vleesvarkensmest bedragen circa 550 euro indien de pakkans en de fraudeprikkel gelijk zijn aan één en ervan uitgaande dat voor $80 \%$ is gefraudeerd met het transport en ook met de boekhouding. Indien de pakkans $1 \%$ is bedraagt de minimale berekende boete per transport circa 55.000 euro bij $80 \%$ fraude.

\subsection{Reflectie op berekening huidige boete}

De huidige boetes zijn berekend op basis van het wederrechtelijk verkregen voordeel maal twee. Dit is conform de wijze waarop bij economische delicten bij de Belastingdienst boetes worden vastgesteld. De vraag was of de huidige boetes te laag zijn als gevolg van de gestegen mestafzetkosten. Indien de boetes zouden worden vastgesteld conform de wijze waarop de huidige boetes zijn vastgesteld, kan geconcludeerd worden dat aanpassing naar boven niet noodzakelijk is omdat de huidige mestafzetprijzen lager zijn dan die bij toepassing van de uitgangspunten voor vaststelling van de huidige boete mogelijk zijn. Ook is het niet de verwachting dat mestafzetkosten in de nabije toekomst dusdanig stijgen dat hierdoor, als dezelfde uitgangspunten worden gehanteerd als bij de vaststelling van de huidige boete, de huidige boetes te laag zouden zijn.

De bovengrens van de mestafzetkosten wordt voornamelijk bepaald door de kosten van het duurste afzetalternatief. Dit alternatief is het verwerken van mest tot droge mestkorrels voor de export. De poorttarieven hiervan bedragen circa 16-18 euro (Luesink et al., 2016). In dat licht bezien hoeven de huidige mestboetes als gevolg van de gestegen mestprijzen niet te worden verhoogd.

Overigens waren de mestafzetprijzen de laatste jaren wel hoger door een gebrek aan verwerkingscapaciteit. Zo bedroeg in het laatste half jaar van 2018 volgens DCA de afzetprijs op de vrije markt over lange afstand van vleesvarkensdrijfmest tussen de 25 en 28 euro per ton. Dus op korte termijn bij onvoldoende mestverwerkingscapaciteit kunnen de prijzen op de vrije markt voor de afzet van vleesvarkensdrijfmest hoger zijn dan de poorttarieven van mestverwerkers. 
De ontwikkeling van de afzetkosten voor rundvee-, varkens-, en pluimveemest

- De mestafzetkosten zijn in de periode 2010-2016 gestegen in de rundvee- en in de varkenshouderij; in de pluimveehouderij zijn ze gedaald.

- De gemiddelde mestafzetkosten per bedrijf verschillen sterk per sector. Deze bedroegen in 2016 voor de melkvee-, pluimvee- en varkenshouderijbedrijven achtereenvolgens circa 6.000, 11.000 en 51.000 euro per bedrijf.

- De mestafzetkosten per bedrijf zijn het hoogst in mestconcentratiegebied Zuid.

De benodigde hoogte van de boete per kilogram stikstof en fosfaat voor het overschrijden van de gebruiksnormen op basis van de mestafzetkosten en de pakkans bij fraude

- Uitgaande van een fraudeprikkel gelijk aan één en een pakkans van $100 \%$ en de mestafzetprijzen van 2016 en de prijsverhouding van stikstof : fosfaat van 7:11, bedraagt de minimaal benodigde boete voor stikstof 1,$9 ; 0,2$ en 1,6 euro per $\mathrm{kg} \mathrm{N}$ voor respectievelijk rundveemest, pluimveemest en varkensmest. Voor fosfaat bedraagt deze 2,9; 0,3 en 2,5 euro per $\mathrm{kg} \mathrm{P}_{2} \mathrm{O}_{5}$.

- Indien de pakkans 10 of 5\% bedraagt kunnen de minimaal benodigde boetes die berekend zijn bij een pakkans van $100 \%$ en een fraudeprikkel van één eenvoudig worden vermenigvuldigd met een factor 10 dan wel 20.

- Indien uitgegaan wordt van prijsverhoudingen voor stikstof en fosfaat van 1:3 en 0:1 worden de verschillen in de minimaal benodigde boete per $\mathrm{kg}$ stikstof en fosfaat tussen de onderscheiden mestsoorten groter. Indien met een gelijke boete voor de stikstof en fosfaat in alle mestsoorten zou worden gerekend, voldoet de prijsverhouding 7:11 het best van de drie doorgerekende prijsverhoudingen.

- Bij kleine pakkansen voldoet de gehanteerde berekeningsmethode voor de minimaal benodigde boete voor stikstof en fosfaat niet. Als gevolg van de veronderstelde zeer kleine pakkans zijn de berekende boetes extreem hoog en hierdoor niet gerelateerd aan het mogelijk genoten economisch voordeel als gevolg van de onjuist afgezette stikstof en fosfaat.

\section{Aansluiting van de berekende boetes bij de handhavingspraktijk, de eerder gehanteerde methode voor het berekenen van de boete en aansluiting bij bestraffen andere economische delicten}

- Omdat er veel onzekerheid is over de daadwerkelijke pakkans bij het onjuist afzetten van mest is het moeilijk om op basis hiervan de benodigde hoogte van de boetes te berekenen.

- Het lijkt daarom zinvoller om de minimaal benodigde hoogte van de boetes te baseren op de berekeningswijze en uitgangspunten waarmee de huidige boetes zijn berekend. Deze uitgangspunten sluiten tevens aan bij de handhaving van economische delicten door de Belastingdienst.

\section{Moeten de mestboetes worden bijgesteld?}

- Gegeven de gehanteerde uitgangspunten voor het berekenen van de huidige boetes zijn de huidige mestafzetkosten (2016) lager dan op basis van de uitgangspunten mogelijk is. Gegeven de destijds gehanteerde uitgangspunten dat de hoogte van de boete gebaseerd is op de niet gemaakte mestafzetkosten plus een even groot bestraffend element, zijn de huidige mestafzetkosten meer dan twee keer zo laag. Dit betekent dat de huidige boetes voor het overschrijden van de gebruiksnormen niet naar boven hoeven te worden bijgesteld vanwege de gestegen mestafzetkosten in deze periode. Ook uit de workshop met handhavers van de mestwetgeving kwam naar voren dat de hoogte van de boetes voldoen.

- De boetes in bijlage $M$ voor administratieve overtredingen voldoen naar de mening van de workshop met handhavers niet. De boetes worden in combinatie met de pakkans als te laag ervaren. Verwacht wordt dat maatwerk zodat in het geval van grotere overtredingen hogere boetes kunnen worden opgelegd, effectiever zijn. Ook het beboeten van klanten van de intermediair (veehouders en akkerbouwers), indien ze via de intermediair in overtreding zijn geraakt, kan effectief zijn. 
- Naast de boetes via het bestuursrecht, kunnen in het strafrecht naast boetes ook andere straffen zoals taakstraffen of beslaglegging op het wagenpark worden opgelegd. Deze zouden veel effectiever kunnen zijn dan het opleggen van boetes. 


\section{Literatuur en websites}

Auditdienst Rijk (2018). Onderzoek Sanctiebeleid Mestwetgeving. Den Haag, Auditdienst Rijk, Ministerie van Financiën, onderzoeksrapport 2018-0000177082.

Koeijer, T.J. de, C. de Lauwere, H.H. Luesink en H. Prins (2018) Handelsverkeer in de mestmarkt: opties voor interventies, Wageningen, Wageningen Economic Research, rapport 2018-057.

LNV (2018) Versterke Handhavingsstrategie Mest, Rijksoverheid Publicatienummer 115770.

Luesink H., R. Postma2, M.J. Smits, L. van Schöll en T. de Koeijer (2016) Effect afzet mestverwerkingsproducten bij wettelijke status kunstmest of EG-meststof, LEI rapport nr. 2016-034, LEI, Wageningen UR.

Oude Lansink, A.G.J.M. (2018), leerstoelgroep Business Economics, Wageningen UR, persoonlijke mededeling 24 oktober 2018.

RVO.nl (2018) https://www.rvo.nl/sites/default/files/2018/01/Tabel-5-Forfaitaire-stikstof-enfosfaatgehalten-in-dierlijke-mest-2018.pdf

Velthof, G.L., T.J. de Koeijer, J.J. Schroder, M. Timmerman, A. Hooijboer, J. Rozemeijer, C. van Bruggen en P. Groenendijk (2017) Effecten van het mestbeleid op landbouw en milieu: Beantwoording van de ex-postvragen in het kader van de evaluatie van de meststoffenwet, Wageningen: Wageningen Environmental Research, (Wageningen Environmental Research rapport 2782) - 139 


\section{Bijlage 1 Minimaal benodigde boete bij pakkans $=100 \%$ en fraudeprikkel $=1$}

Minimale hoogte boete (euro/kg) voor stikstof $(\mathrm{N})$ en fosfaat $\left(\mathrm{P}_{2} \mathrm{O}_{5}\right)$ onderscheiden per mestconcentratiegebied zuid, oost en overig en totaal Nederland op basis van de mestafzetprijzen van 2016 bij pakkans $=100 \%$ en fraudeprikkel=1

\begin{tabular}{|c|c|c|c|c|c|c|c|}
\hline Mestsoort & gebied & Verhouding boete & & Verhouding boete & & Verhouding boete & \\
\hline & & $\mathrm{N}: \mathrm{P}_{2} \mathrm{O}_{5}$ & & $\mathbf{N}: \mathrm{P}_{2} \mathrm{O}_{5}$ & & $\mathrm{~N}: \mathrm{P}_{2} \mathrm{O}_{5}$ & \\
\hline Prijsverhouding & & $7: 11$ & & $1: 3$ & & $0: 1$ & \\
\hline \multirow[t]{4}{*}{ Rundveemest } & Zuid & 2,2 & 3,4 & 1,6 & 4,8 & 0 & 9,1 \\
\hline & Oost & 2,2 & 3,4 & 1,6 & 4,8 & 0 & 9,1 \\
\hline & Overig & 1,5 & 2,4 & 1,2 & 3,5 & 0 & 6,5 \\
\hline & totaal & 1,9 & 2,9 & 1,4 & 4,2 & 0 & 7,9 \\
\hline \multirow[t]{4}{*}{ Pluimveemest } & Zuid & 0,2 & 0,3 & 0,1 & 0,3 & 0 & 0,4 \\
\hline & Oost & 0,2 & 0,3 & 0,1 & 0,3 & 0 & 0,4 \\
\hline & Overig & 0,2 & 0,3 & 0,1 & 0,3 & 0 & 0,4 \\
\hline & totaal & 0,2 & 0,3 & 0,1 & 0,3 & 0 & 0,4 \\
\hline \multirow[t]{4}{*}{ Varkensmest } & Zuid & 1,5 & 2,4 & 1,1 & 3,2 & 0 & 5,0 \\
\hline & Oost & 1,8 & 2,8 & 1,3 & 3,8 & 0 & 5,9 \\
\hline & Overig & 1,3 & 2,0 & 0,9 & 2,7 & 0 & 4,2 \\
\hline & totaal & 1,6 & 2,5 & 1,1 & 3,4 & 0 & 5,3 \\
\hline
\end{tabular}




\section{Bijlage 2 Minimaal benodigde boete bij oplopende pakkans $(0,1-1 \%)$ en fraudeprikkel van 0,$6 ; 1$ en 1,4}

Minimale hoogte boete (euro/kg) voor stikstof $(N)$ op basis van de mestafzetprijzen van 2016 bij oplopende pakkans van 0,1 tot $1 \%$ en fraudeprikkel variërend van 0,6; 1 en 1,4 uitgaande van de prijsverhouding stikstof : fosfaat van 7:11

\begin{tabular}{|c|c|c|c|c|c|c|c|c|c|c|}
\hline Pakkans & $0,1 \%$ & $0,2 \%$ & $0,3 \%$ & $0,4 \%$ & $0,5 \%$ & $0,6 \%$ & $0,7 \%$ & $0,8 \%$ & $0,9 \%$ & $1 \%$ \\
\hline $\begin{array}{l}\text { rundveedrijfmest } \\
(\mathrm{fr} \text { prikkel } 0,6 \text { ) }\end{array}$ & 1114 & 557 & 371 & 278 & 223 & 186 & 159 & 139 & 124 & 111 \\
\hline rundveedrijfmest & 1856 & 928 & 619 & 464 & 371 & 309 & 265 & 232 & 206 & 186 \\
\hline $\begin{array}{l}\text { rundveedrijfmest } \\
\text { (fr prikkel } 1,4 \text { ) }\end{array}$ & 2599 & 1299 & 866 & 650 & 520 & 433 & 371 & 325 & 289 & 260 \\
\hline $\begin{array}{l}\text { pluimvee } \\
\text { (fr prikkel } 0,6 \text { ) }\end{array}$ & 97 & 49 & 32 & 24 & 19 & 16 & 14 & 12 & 11 & 10 \\
\hline Pluimvee & 162 & 81 & 54 & 41 & 32 & 27 & 23 & 20 & 18 & 16 \\
\hline $\begin{array}{l}\text { pluimvee } \\
\text { (fr prikkel 1,4) }\end{array}$ & 227 & 114 & 76 & 57 & 45 & 38 & 32 & 28 & 25 & 23 \\
\hline $\begin{array}{l}\text { Vleesvarkens } \\
\text { (fr prikkel 0,6) }\end{array}$ & 970 & 485 & 323 & 242 & 194 & 162 & 139 & 121 & 108 & 97 \\
\hline Vleesvarkens & 1617 & 808 & 539 & 404 & 323 & 269 & 231 & 202 & 180 & 162 \\
\hline $\begin{array}{l}\text { Vleesvarkens } \\
\text { (fr prikkel } 1,4 \text { ) }\end{array}$ & 2263 & 1132 & 754 & 566 & 453 & 377 & 323 & 283 & 251 & 226 \\
\hline
\end{tabular}

Minimale hoogte boete (euro/ $\mathrm{kg}$ ) voor fosfaat $\left(\mathrm{P}_{2} \mathrm{O}_{5}\right)$ op basis van de mestafzetprijzen van $2016 \mathrm{bij}$ oplopende pakkans van 0,1 tot $1 \%$ en fraudeprikkel variërend van 0,$6 ; 1$ en 1,4 uitgaande van de prijsverhouding stikstof : fosfaat van 7:11

\begin{tabular}{|c|c|c|c|c|c|c|c|c|c|c|}
\hline Pakkans & $0,1 \%$ & $0,2 \%$ & $0,3 \%$ & $0,4 \%$ & $0,5 \%$ & $0,6 \%$ & $0,7 \%$ & $0,8 \%$ & $0,9 \%$ & $1 \%$ \\
\hline $\begin{array}{l}\text { rundveedrijfmest } \\
(\mathrm{fr} \text { prikkel } 0,6)\end{array}$ & 1750 & 875 & 583 & 438 & 350 & 292 & 250 & 219 & 194 & 175 \\
\hline rundveedrijfmest & 2917 & 1458 & 972 & 729 & 583 & 486 & 417 & 365 & 324 & 292 \\
\hline $\begin{array}{l}\text { rundveedrijfmest } \\
\text { (fr prikkel } 1,4 \text { ) }\end{array}$ & 4084 & 2042 & 1361 & 1021 & 817 & 681 & 583 & 510 & 454 & 408 \\
\hline $\begin{array}{l}\text { pluimvee } \\
\text { (fr prikkel } 0,6 \text { ) }\end{array}$ & 153 & 77 & 51 & 38 & 31 & 26 & 22 & 19 & 17 & 15 \\
\hline Pluimvee & 255 & 128 & 85 & 64 & 51 & 43 & 36 & 32 & 28 & 26 \\
\hline $\begin{array}{l}\text { pluimvee } \\
\text { (fr prikkel 1,4) }\end{array}$ & 357 & 179 & 119 & 89 & 71 & 60 & 51 & 45 & 40 & 36 \\
\hline $\begin{array}{l}\text { Vleesvarkens } \\
\text { (fr prikkel } 0,6 \text { ) }\end{array}$ & 1524 & 762 & 508 & 381 & 305 & 254 & 218 & 191 & 169 & 152 \\
\hline Vleesvarkens & 2540 & 1270 & 847 & 635 & 508 & 423 & 363 & 318 & 282 & 254 \\
\hline $\begin{array}{l}\text { vleesvarkens } \\
\text { (fr prikkel } 1,4 \text { ) }\end{array}$ & 3557 & 1778 & 1186 & 889 & 711 & 593 & 508 & 445 & 395 & 356 \\
\hline
\end{tabular}


Minimale hoogte boete (euro/kg) voor stikstof $(N)$ op basis van de mestafzetprijzen van 2016 bij oplopende pakkans van 0,1 tot $1 \%$ en fraudeprikkel variërend van 0,6; 1 en 1,4 uitgaande van de prijsverhouding stikstof : fosfaat van $1: 3$

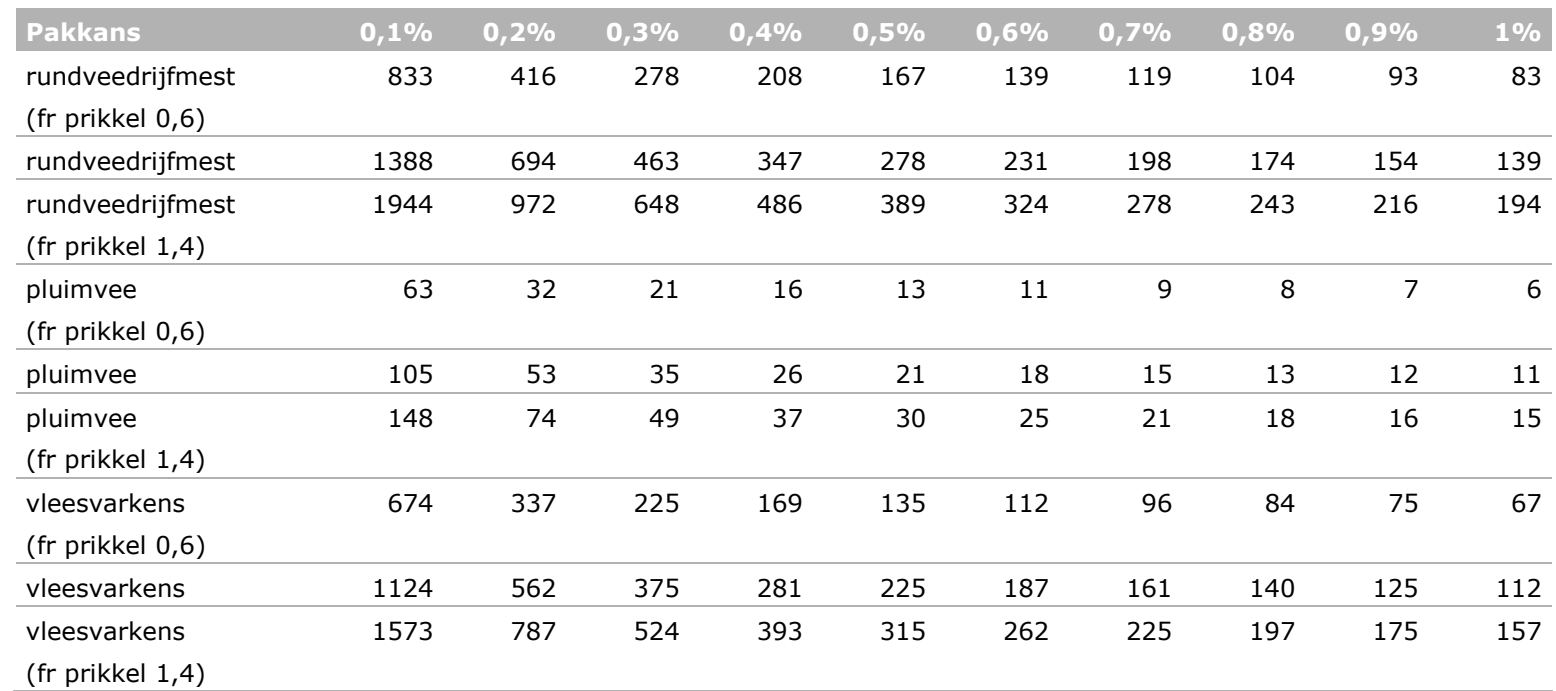

Minimale hoogte boete (euro/kg) voor fosfaat $\left(\mathrm{P}_{2} \mathrm{O}_{5}\right)$ op basis van de mestafzetprijzen van 2016 bij oplopende pakkans van 0,1 tot $1 \%$ en fraudeprikkel variërend van 0,6; 1 en 1,4 uitgaande van de prijsverhouding stikstof : fosfaat van $1: 3$

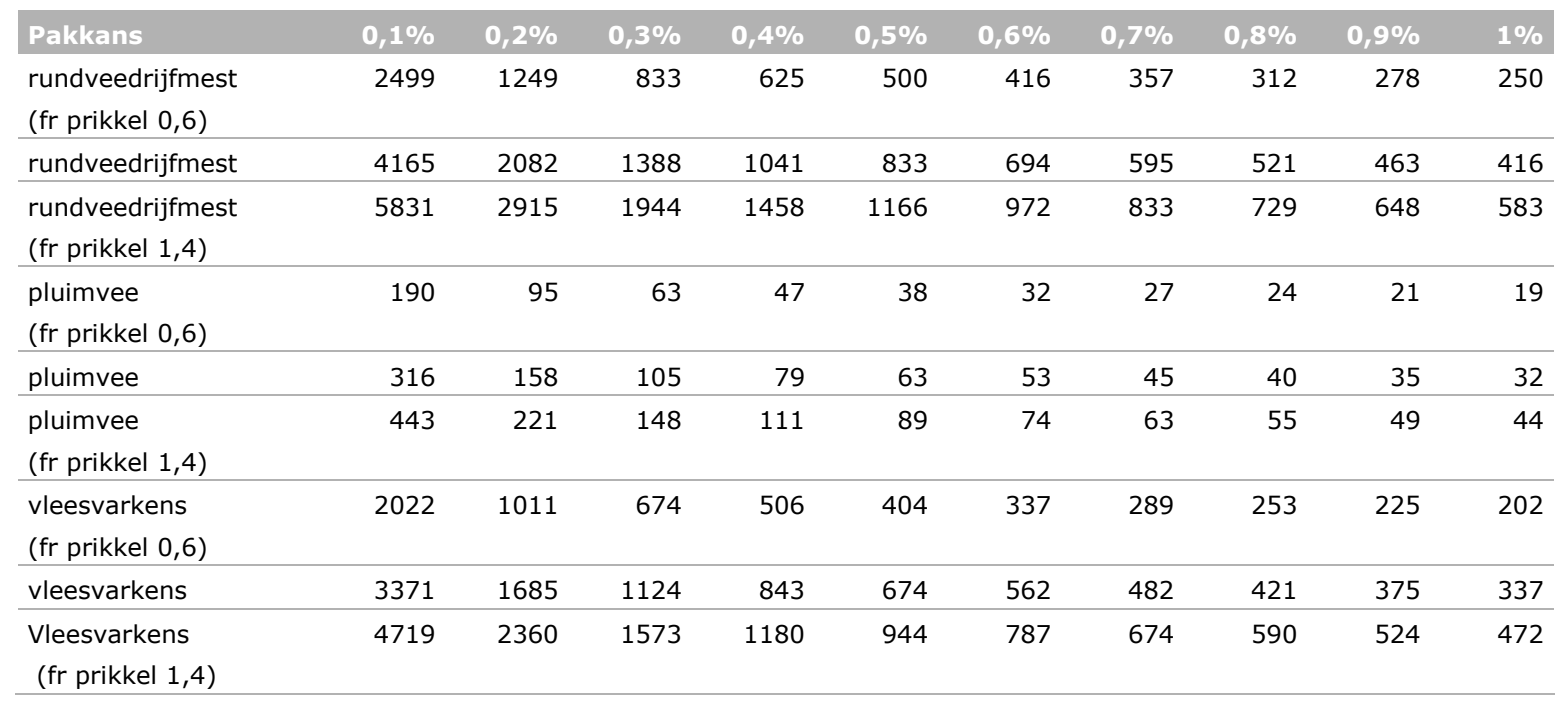


Minimale hoogte boete (euro/kg) voor fosfaat $\left(\mathrm{P}_{2} \mathrm{O}_{5}\right)$ op basis van de mestafzetprijzen van 2016 bij oplopende pakkans van 0,1 tot $1 \%$ en fraudeprikkel variërend van 0,6; 1 en 1,4 uitgaande van de prijsverhouding stikstof : fosfaat van 0:1

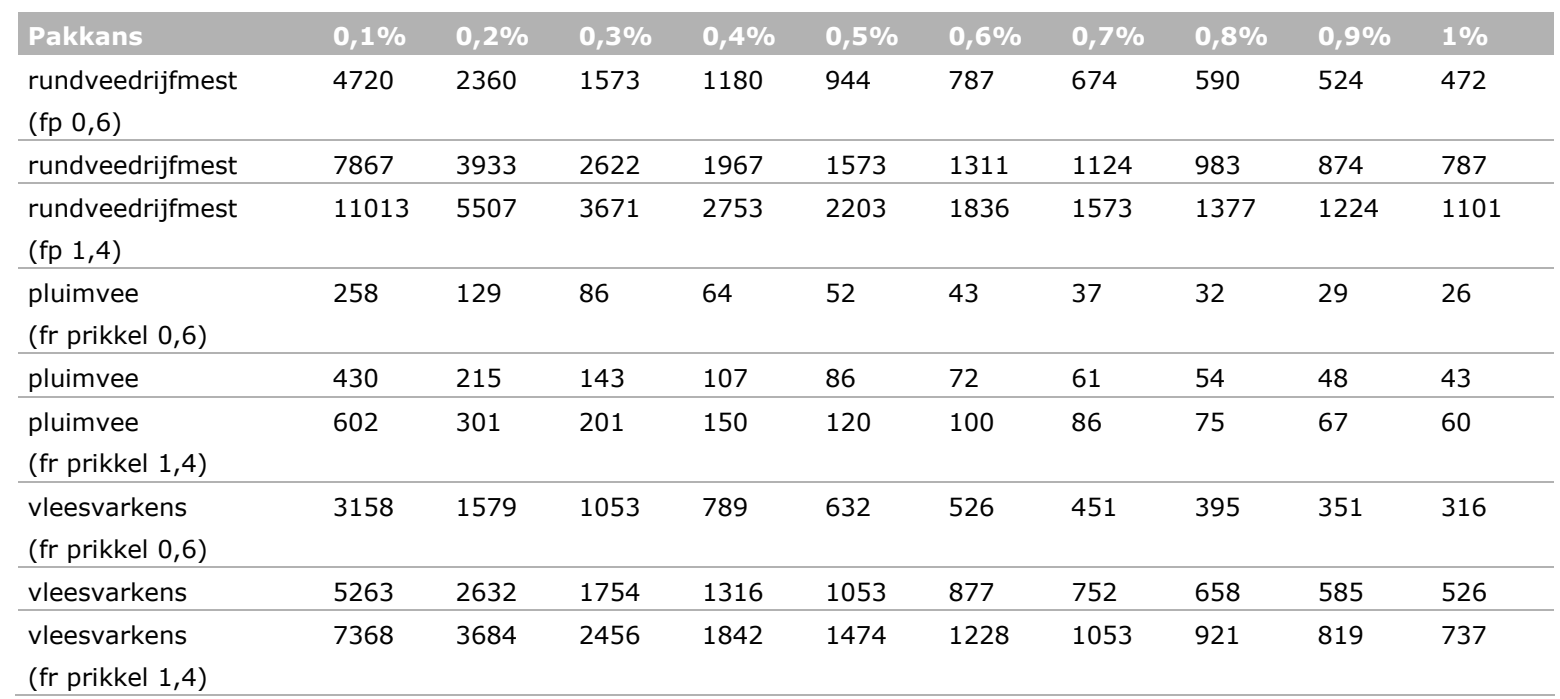


Wageningen Economic Research Postbus 29703

2502 LS Den Haag

T 0703358330

Ecommunications.ssg@wur.nl

www.wur.nl/economic-research

Wageningen Economic Research NOTA

2019-016
De missie van Wageningen University \& Research is 'To explore the potential of nature to improve the quality of life'. Binnen Wageningen University \& Research bundelen Wageningen University en gespecialiseerde onderzoeksinstituten van Stichting Wageningen Research hun krachten om bij te dragen aan de oplossing van belangrijke vragen in het domein van gezonde voeding en leefomgeving. Met ongeveer 30 vestigingen, 5.000 medewerkers en 10.000 studenten behoort Wageningen University \& Research wereldwijd tot de aansprekende kennisinstellingen binnen haar domein. De integrale benadering van de vraagstukken en de samenwerking tussen verschillende disciplines vormen het hart van de unieke Wageningen aanpak. 


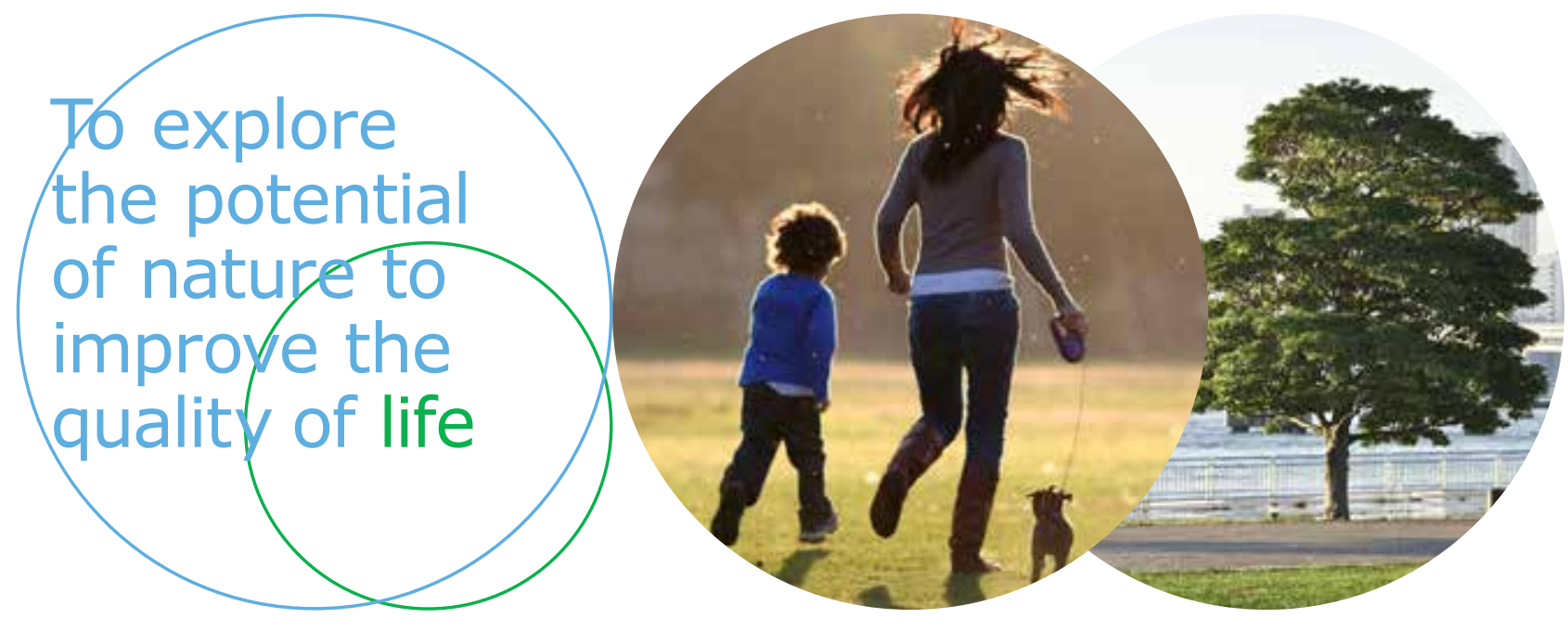

Wageningen Economic Research Postbus 29703

2502 LS Den Haag

E communications.ssg@wur.nl

$T+31(0) 703358330$

www.wur.nl/economic-research

De missie van Wageningen University \& Research is 'To explore the potential of nature to improve the quality of life'. Binnen Wageningen University \& Research bundelen Wageningen University en gespecialiseerde onderzoeksinstituten van Stichting Wageningen Research hun krachten om bij te dragen aan de oplossing van belangrijke vragen in het domein van gezonde voeding en leefomgeving. Met ongeveer 30 vestigingen, 5.000 medewerkers en 10.000 studenten behoort Wageningen University \& Research wereldwijd tot de aansprekende kennis-

Nota 2019-016 instellingen binnen haar domein. De integrale benadering van de vraagstukken en de samenwerking tussen verschillende disciplines vormen het hart van de unieke Wageningen aanpak. 